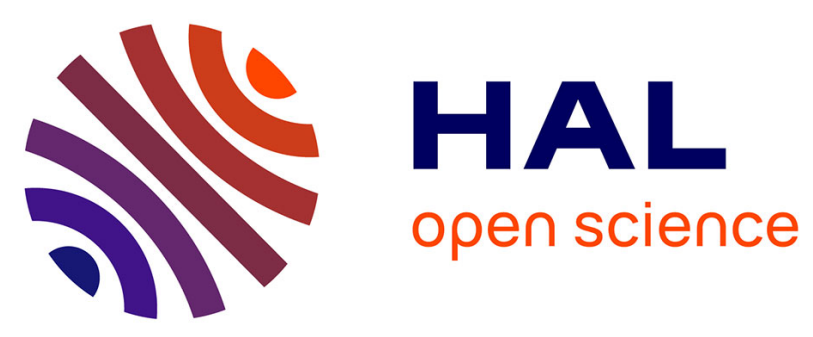

\title{
Food Supply Strategies in the Romanian Eneolithic: Sheep/Goat Husbandry and Fishing Activities from Hârşova Tell and Borduşani-Popină (5th Millennium $\mathrm{BC})$
}

Stéphanie Bréhard, Valentin Radu, Alexis Martin, Pauline Hanot, Dragomir Popovici, Adrian Bălăşescu

\section{To cite this version:}

Stéphanie Bréhard, Valentin Radu, Alexis Martin, Pauline Hanot, Dragomir Popovici, et al.. Food Supply Strategies in the Romanian Eneolithic: Sheep/Goat Husbandry and Fishing Activities from Hârşova Tell and Borduşani-Popină (5th Millennium BC). European Journal of Archaeology, 2014, 17 (3), pp.407-433. 10.1179/1461957113Y.0000000051 . hal-02360354

\section{HAL Id: hal-02360354 https://hal.science/hal-02360354}

Submitted on 13 Nov 2019

HAL is a multi-disciplinary open access archive for the deposit and dissemination of scientific research documents, whether they are published or not. The documents may come from teaching and research institutions in France or abroad, or from public or private research centers.
L'archive ouverte pluridisciplinaire HAL, est destinée au dépôt et à la diffusion de documents scientifiques de niveau recherche, publiés ou non, émanant des établissements d'enseignement et de recherche français ou étrangers, des laboratoires publics ou privés. 
Food supply strategies in the Romanian Eneolithic: sheep/goat husbandry and fishing activities from Hârşova tell and Borduşani-Popină (5th millennium BC)

Stéphanie Bréhard, Valentin Radu, Alexis Martin, Pauline Hanot, Dragomir Popovici and Adrian Bălăşescu

NOTICE: this is the post-print version of a work that was accepted for publication in European Journal of Archaeology. Changes resulting from the publishing process, such as editing, corrections, structural formatting, and other quality control mechanisms may not be reflected in this document. Changes may have been made to this work since it was submitted for publication. A definitive version was subsequently published in European Journal of Archaeology 17 (3) 2014, 407-433.

European Journal of Archaeology is available online at:

\section{https://doi.org/10.1179/1461957113Y.0000000051}


Food supply strategies in the Romanian Eneolithic: sheep/goat husbandry and fishing activities from Hârşova tell and Borduşani-Popină $\left(5^{\text {th }}\right.$ millennium BC)

Stéphanie Bréhard ${ }^{1,2}$, Valentin Radu ${ }^{1}$, Alexis Martin $^{3}$, Pauline Hanot $^{2}$, Dragomir Popovici ${ }^{1}$ and Adrian Bălăşescu ${ }^{1}$

\footnotetext{
${ }^{1}$ National History Museum of Romania, Calea Victoriei nr. 12, 030026, sector 3, Bucharest, Romania

${ }^{2}$ CNRS - Muséum national d'Histoire naturelle, UMR 7209, CP 56, 55 rue Buffon, F-75005 Paris, France

${ }^{3}$ Muséum national d'Histoire naturelle, UMR 7208, 43 rue Cuvier, F-75005 Paris, France.
}

\begin{abstract}
Previously observed specialisation in sheep/goat kill-off patterns from Romanian Eneolithic sites raises the question of a limited duration of the slaughtering period. In order to provide reliable month of death distribution for sheep/goats, the approach developed here takes into account uncertainties regarding the age-at-death and the month of birth, based on classical archaeozoological techniques. We show that sheep slaughtering rarely occurred from late spring to early autumn or from summer to mid-fall, both at Hârşova-tell and BorduşaniPopină. Conversely, it is very likely that fishing activities took place primarily from spring to early autumn. This points to the existence of seasonal and complementary food supply strategies at both sites. Several possible explanations for these seasonal strategies are discussed. We also highlight the homogeneity in the management of domestic herds between the two sites, raising the question of a certain standardisation in pastoral practices on a larger scale.
\end{abstract}

\title{
Key-words
}

South-eastern Romania, Gumelnița culture, sheep/goats, fish, season of death, seasonal strategies 


\section{Introduction}

In south-eastern Europe, Eneolithic cultures represent a crucial period in the evolution of prehistoric societies as they are characterized by the development of copper metallurgy, specialised workshops (ceramic and flint-processing areas are the most common in Romania; Ellis, 1984; Marinescu-Bîlcu, 2002; Manolakakis, 2007; Chapman, 2010; Popovici, 2010), and accentuated social differentiation (Renfrew, 1978; Todorova, 1978; MarinescuBîlcu, 2001; Chapman et al., 2006; Guilaine, 2007; Slavchev, 2008). In south-eastern Romania and north-eastern Bulgaria, the Eneolithic period is also marked by the appearance and the increasing density of tell-dwelling. These tells can be highly structured settlements (e.g., Todorova, 1978; Bailey, 2000; Ştefan, 2010). As for animal management, a first analysis of husbandry practices developed for sheep in south-eastern Romania during the Late Eneolithic showed that they were consistent and specialised (Bréhard \& Bălăşescu, 2012). This homogeneity is quite unexpected given both the wide diversity in the faunal spectra that characterises this period and the differences, in location and size for instance, between the studied sites (op. cit.). This raised the question of a possible standardisation in pastoral practices, which would be somewhat reminiscent of the similarities in settlement organisation observed between Eneolithic tell sites, especially in north-eastern Bulgaria (e.g., Todorova, 1978; Bailey, 2000).

We also pointed out that specialisation in sheep/goat management is not common in the European Neolithic and Eneolithic (op. cit.). During this period in Europe, sheep births occurred, in all likelihood, during a rather restricted period (Balasse \& Tresset, 2007; Blaise \& Balasse, 2011; Balasse et al., 2012a, 2013). Therefore, the specialised practices observed for this species - the main product sought out by the inhabitants of the studied tell sites was tender meat - could be imputed to or could result from the limited duration of the slaughtering period. In this case, the question arises as to whether this was linked to the availability of other resources (wild resources especially) or to other constraints, and did Eneolithic communities develop strategies to ensure the supply of animal protein throughout the year?

The objective of our study is to analyse the seasonal timing of animal deaths, to explore the existence of seasonal slaughtering for domestic species and of seasonal fishing/gathering activities, and consequently examine whether complementary food supply strategies were developed by Eneolithic communities. We also aim to check whether the similarities observed between the kill-off patterns established for sheep point to similar distributions for season of death, and therefore if the hypothesis of a certain standardisation in husbandry practices during the Late Eneolithic is plausible. 
Numerous studies dealing with the seasonal slaughtering of mammals have been published (e.g., for the Holocene, Legge \& Rowley-Conwy, 1991; Rowley-Conwy, 1993; O'Connor, 1998; Ervynck, 2005; Halstead, 2005; Helmer et al., 2005; Frankel et al., 2013), but reliable and accurate information concerning the season/month of death distribution is rarely obtained for domestic species. Apart from a few studies using skeletochronology techniques (e.g., Kasparov, 1994; Pike-Tay et al., 2004), this is partly due to methodological and zootechnical factors (see O'Connor, 1998; Milner, 2005). In order to reliably attribute a season/month of death to archaeological samples, methods conducive to precise age-atdeath estimates are necessary, and birth season(s) must be known. Moreover, for the European Neolithic, the season of death for domestic species is often studied to provide evidence for permanent or temporary occupation. In this way, the presence/absence of data per month/season is often targeted, rather than quantitative distributions per month/season.

In order to propose reliable season of death distributions for domestic mammals, we developed an approach, based on classical archaeozoological techniques (recording eruption and wear stages in mandibles), that takes into account uncertainties specific to archaeological data. Simulations (1000 random runs) were performed to take into consideration both the ranges of age estimates and the existence of different possibilities for the month of birth. We applied this approach to sheep/goats as modern data sets allow both reliable and exact age-at-death estimates for these species (Deniz \& Payne, 1982; Jones, 2006), unlike cattle for which age estimates remain quite wide (Jones \& Sadler, 2012a, 2012b). Moreover, recent studies provided information on seasonality and season of birth for Neolithic sheep (Balasse \& Tresset, 2007; Blaise \& Balasse, 2011; Balasse et al., 2012a, 2013) whereas for pigs, only hypotheses based on modern or historical references can be used for the moment (e.g., Frémondeau, 2012). Finally, sheep/goats played an important role in the animal economy during the Eneolithic period in south-eastern Romania (Bréhard \& Bălăşescu, 2012).

Two Eneolithic tell sites from south-eastern Romania were selected for this study: Hârşova tell and Borduşani-Popină. They both provided large assemblages of exceptionally wellpreserved sheep/goat remains (complete hemimandibles are common). The two sites display similar characteristics in that they are both large tells, located close to the Danube River, with Eneolithic occupations from the Gumelnița culture, and large game was not a pivotal component of the animal economy. At the same time, clear differences between the sites exist: sheep/goats were the main domestic species at Hârşova tell whereas there was a more balanced representation of cattle and sheep/goats at Borduşani-Popină and a significant proportion of domestic pig. 
Along with the sheep/goat season of death, we also examined fishing seasons as this activity played an important role at both sites (Bălăşescu et al., 2005; Radu, 2011). Fish were readily available sources of animal protein, given the location of these settlements. In order to provide information on fishing seasons, we studied the biological and ecological characteristics of the identified fish species (such as spawning periods) and size distribution, following Pike-Tay et al. (2004) and Bartosiewicz (2007). At Hârşova tell, these results are compared with those already obtained from skeletochronology analyses.

\section{Archaeological contexts}

Figure 1 indicates the location of the two sites selected for this study. They are among the largest Gumelnița tell sites excavated in Romania to date. Hârşova tell is located on a Danube river terrace. The base measures $60 \times 200 \mathrm{~m}$ and archaeological levels are preserved over a thickness of $12 \mathrm{~m}$ in the central part of the site (the Gumelnița levels represent a height of about $7 \mathrm{~m}$ ). The original area of the tell is estimated at about 2 ha, but it has been partly destroyed by the Danube River. The studied faunal remains come from the excavations conducted since 1993. Altogether, about $4 \mathrm{~m}$ in height and $400 \mathrm{~m}^{2}$ have been excavated for the Gumelnița A2. Borduşani-Popină is located in a large island bordered by the Danube River and by a branch of this river (Borcea). The area is periodically flooded. The base measures $118 \times 188 \mathrm{~m}$ and preserved archaeological levels (Boian and Gumelnița A cultures) represent a thickness of about $7 \mathrm{~m}$. The studied faunal remains are from the excavations conducted since 1993. Approximately $3 \mathrm{~m}$ in height and $800 \mathrm{~m}^{2}$ have been excavated for the Gumelnița A2. Both tells are excavated using the same methodology (Randoin et al., 2000; Popovici et al., 2001).

Both tell sites yielded dwellings (sometimes gutted by fire) characterized by floors made of loess or fine sandy sediments, often mixed with vegetal materials (e.g., Haită, 2012). They are placed in rows with alleyways running between them (Popovici et al., 2001; Popovici, 2010). Areas of household refuse have also been identified. These result from mammal, fish, mollusc and cereal processing, amongst others (e.g., Moise, 2000; Monah, 2000; Haită \& Radu, 2003). Some burials have also been excavated and skeletons were often concealed under the floor of a building (Marinescu-Bîlcu, 2001; Popovici et al., 2001, 2003). The fact that buildings were often rebuilt at the same place, according to the same plan (and with almost the same dimensions), suggests that these tell sites were highly organized settlements (Marinescu-Bîlcu, 2001; Popovici et al., 2001; see Bailey, 2000 for similar cases 
in north-eastern Bulgaria). Based on this organization and the different types of archaeological structures identified, a permanent settlement function is proposed for both tells (Popovici et al., 2000, 2001; Marinescu-Bîlcu, 2001; Haită \& Radu, 2003).

The duration of the Gumelnița A2 occupations is difficult to estimate for these sites. To date, there are not enough radiocarbon dates (4 per site) to advance accurate estimates. Currently available dates indicate occupations between c. 4350 and 4050 cal BC at Hârşova tell (Bréhard \& Bălăşescu, 2012), and between c. 4500 and 4250 cal BC at Borduşani-Popină (Table 1 and Gillis et al., 2013).

\subsection{Archaeozoological contexts}

Generally speaking, this type of site is conducive to the good preservation of animal remains. Tell sites are stratified settlements conserved in very specific conditions (in particular a dry climate) that reduce the process of erosion and preserve evidence of human activities. Hârşova tell and Borduşani-Popină have yielded several wooden platforms (Popovici et al., 2000,2003 ), which are evidence of the low level of degradation characteristic of tell sites.

Both sites provided large amounts of fish and mollusc remains along with mammal bones. Based on NISP, fish represent 92 per cent of the archaeozoological remains at Hârşova tell and 33 per cent at Borduşani-Popină; mammals represent 2 per cent and 43 per cent, and bivalves 5 per cent and 20 per cent, respectively (Bălăşescu et al., 2005: Table 1; $\mathrm{NISP}=283,492$ and 32,893). Due to the large size of the assemblages, about 20 species have been identified for fish. The wels catfish, the pikeperch, the common carp and the northern pike are the most common species (op. cit.). For mammals, both sites are characterized by the important role of husbandry. Game (wild boar and deer mainly) represents 23 and 21 per cent of mammal remains. Within domestic species, sheep/goats are predominant at Hârşova tell (26 per cent of the mammal remains whereas cattle represent 11 per cent) while there is a more balanced representation of cattle and sheep/goats (21 and 17 per cent respectively) at Borduşani-Popină (Bréhard \& Bălăşescu, 2012).

\section{Material}


Large assemblages of archaeozoological remains are available at both sites and sample size always exceeds 5000 NISP, regardless of the group (mammals or fish; and in 3 cases out of 4, it exceeds 10,000 NISP; Bălăşescu et al., 2005). All the archaeological structures with a high archaeozoological potential have been sieved, which partly explains the large size of the fish assemblages (Bălăşescu et al., 2005; Table 6, see below). At the site level, large dental assemblages are also available for sheep/goats. Hemimandibles and isolated lower teeth with broad age estimates represent 240 NISP at Hârşova tell and 154 NISP at BorduşaniPopină. These assemblages contain about 180 complete hemimandibles.

The studied fish and sheep/goat remains come from several archaeological structures, and of different kinds: areas of household refuse (e.g., C136, C521, C952, C963, C1027), foundation trenches (e.g., C33, C98, C349, C237, C279, C281), dwellings (e.g., SL68), alleyways (e.g., C332), etc. (each structure comprises several or hundreds of stratigraphic units). These different kinds of structure have been described in Popovici et al. (2000, 2001, 2003), Radu (2000), Haită \& Radu (2003), Tomescu et al. (2003) and Haită (2012). Data presented in this study are global data. It is not possible to provide several large samples per site, each characterizing one archaeological structure or one occupation, as the stratigraphic profiles are not completed. It will be possible to work on a smaller scale and compare the different structures excavated for one occupation (and compare the different occupations) when the final stratigraphic data is available. However, for sheep/goats, we individually analysed several small samples to check whether the global data analysis masks the existence of different practices in some archaeological structures, but given the very small size of the samples, only tendencies can be proposed.

Concerning the published skeletochronology results for Hârşova tell, the analysis of fish vertebrae was conducted for two archaeological structures where large samples were available: areas of household refuse C521 ( $\mathrm{N}=1906)$ and us1523 ( $\mathrm{N}=256)$. For both structures, $4 \mathrm{~mm}$ sieves were used.

\section{Methods}

\subsection{Sheep/goat dental assemblages}

\subsubsection{Taxonomic identification}

It is essential to determine the species of archaeological mandibles in order to propose age estimates as differences exist between sheep and goat. Jones' observations (2006: 167) 
confirmed that 'the striking difference $[\ldots]$ is in the wear rate of dP4 and the timing of eruption of P4'. This is a deciding factor for both of the selected sites as two-thirds of the studied dental remains (65 and 69 per cent of the teeth, respectively; Bréhard \& Bălăşescu, 2012) are concerned by one of the stages of dP4 life, from eruption to shedding (dP4 lifespan corresponds to age classes $A$ to $D$ from Payne, 1973).

The identification of dentition to the species-level has already been published for Hârşova tell and Borduşani-Popină (Bréhard \& Bălăşescu, 2012). Taxonomic identifications were based on the premolars and we did not identify isolated dP4. As two recent studies confirmed that some of the criteria published for molars are reliable (Zeder \& Pilaar, 2010; Gillis et al., 2011), we analysed both assemblages once again. Given that complete hemimandibles were numerous and that several criteria have thus been taken into account at the same time, the number of remains identified to species level has clearly increased: from 43 to 58 per cent at Hârşova tell and from 38 to 58 per cent at Borduşani-Popină (Table 2). The percentage of sheep increased slightly at Borduşani-Popină.

\subsubsection{Age-at-death estimates}

Precise age-at-death estimates as well as extensive data are required in order to provide reliable information on month of death distribution. The most common data are dP4 crown height (149 data with known species; few measurements are available for molars as that would require breaking the hemimandibles). However, the theoretical formulae proposed by Klein et al. (1983) to estimate an age based on dP4 crown height (linear and quadratic formulae) are not suitable for this study. First, for sheep/goats, correlation between dP4 crown height and age has never been demonstrated based on individuals of known ages. Secondly, Klein et al. (1983) and Pike-Tay et al. (2000) tested this relationship for wapiti $(\mathrm{N}=83)$ and caribou $(\mathrm{N}=152)$, based on large samples (like sheep/goats, these two species are characterized by deciduous teeth with lifespans of about 2 years; see Legge \& RowleyConwy, 1991 for discussion about the speed of replacement). They both concluded that dP4 crown height is not a very accurate predictor of individual age (in general, crown heights methods cannot provide precise estimates of age; e.g., Ducos, 1968; Klein et al., 1983; Gifford-Gonzalez, 1991; Twiss, 2008).

On the other hand, methods providing reliable age-at-death estimates based on eruption and wear stages exist for sheep (Jones, 2006) and goats (Deniz \& Payne, 1982), and narrow age ranges can be obtained for the youngest specimens when hemimandibles are complete. As about 130 complete hemimandibles of known species are available at Hârşova tell and 
Borduşani-Popină for the first age classes (A to D; age classes after Payne, 1973), we used these two modern data sets to estimate age-at-death, with some adjustments (see below).

Despite the problems described above, $\mathrm{dP} 4$ crown heights are sometimes used to determine precise age-at-death for sheep/goats in order to provide month of death distributions. These studies postulate a linear relationship between age and height (Kasparov, 1994; Helmer et al., 2005, Blaise \& Balasse, 2011). Based on our large sample of hemimandibles of known species and estimated age, we examined the relationship between dP4 crown height and age (see subsection 4.1.5. for details concerning the methodology).

We based our study of archaeological teeth on the stages described by Ewbank et al. (1964) for eruption and the codes proposed by Payne (1987) for wear (Table 3, see below). For sheep, we applied the age estimates proposed by Jones (2006), based on 1611 observations of live sheep from the UK (including Soays and unimproved breeds). She showed that mandible stages depending 'on early wear of the latest-erupted tooth provide information almost as reliable as for eruption' (Jones, 2006: 170). As a precaution, we used all records, except outliers (except when the number of observations was less than 20), because 'there is a regular tendency for some Soays to be at earlier stages, and none at later stages of each age class' (Jones, 2006: 166 and appendix). For goats, we used the estimates based on 1256 observations of live Angora goats from Turkey (Deniz \& Payne, 1982). We applied the figures given in Figure 24 (Deniz \& Payne, 1982: 180) where age ranges encompass 95 per cent of cases (following Halstead, 2005).

Jones (2006) proposed that in archaeological samples, the wear rate can be faster than that observed on modern sheep; age estimates may therefore be adjusted. We compared the cross-tabulation of relative wear of dP4 and M1 provided in her study (Jones, 2006: Figure 15) to the Romanian records (sample size for sheep: 122 hemimandibles). This comparison shows that at every M1 wear stage, Romanian dP4 records are never less than the modern median value (except for one mandible) and for stages C1/2 and C5A, some are outside (above) the range of Jones' observations (i.e., at every M1 wear stage, Romanian dP4 are, in general, more worn than modern dP4). This strongly suggests that the wear rate is faster for the Romanian Eneolithic sheep. Therefore, for sheep, the absolute age proposed for the archaeological hemimandibles is based on the 'latest-erupted tooth'. We did not use the dP4 and then the M1 wear rate to reduce the range obtained (for example, for a mandible of sheep with $\mathrm{M} 1$ at stage $5 \mathrm{~A}$, i.e. 6-10 months, and dP4 at stage $15 \mathrm{~K}$, i.e. 9-21 months, the estimated age range used is 6-10 months, rather than 9-10 months).

For goats, we first compared the Romanian data with the cross-tabulation of relative wear of dP4 and M2 proposed by Deniz \& Payne (1982: Figure 35). The three examples fall within 
the range of their observations. Although they do not propose dP4 and M1 cross-tabulation, all twelve Romanian examples are in the range of observations for female Angora goats (summarized in Figure 24 from Deniz \& Payne, 1982). Therefore, for goats, wear stages of earlier erupting teeth were used to shorten the range given by the last erupting tooth (4 cases are concerned).

For Deniz \& Payne (1982) and Jones (2006), eruption stage E means "eruption through the gum"; it is therefore more advanced than the Ewbank et al. (1964) code we used for recording archaeological teeth (whereby E means "tooth erupting through bone"). For this reason, we accorded the same absolute age to the second molars recorded as "V-E" as to the teeth recorded as "V". However, the first and second molars recorded as "E" were included in the stage "E/J" proposed by Deniz \& Payne and Jones since it is not possible to rule out gum line cutting.

Finally, only hemimandibles with an age range equal to or less than 5 months were selected for the study (average range: 3.9 months) and the sample size is 110 (Table 2). Right and left hemimandibles are used. No more than four hemimandibles come from the same archaeological structure. Moreover, among the selected hemimandibles, we did not find right and left hemimandibles with exactly the same morphology and a similar wear stage in the same archaeological stratigraphic unit or structure. This suggests that one individual is unlikely to have been taken into account twice.

\subsubsection{Seasonality and season of birth}

To estimate the season/month of death, seasonality and season of birth must be known. Recent stable isotope analyses conducted on archaeological samples suggest that one period of birth was the norm for sheep during the Neolithic period in Europe (Balasse \& Tresset, 2007; Blaise \& Balasse, 2011; Balasse et al., 2012a, 2013). They also show that the birth period was relatively restricted (about 2 to 3 months). In Romania, at Măgura-Boldul lui Moş Ivănuş (beginning of the $7^{\text {th }}$ mil. BC; Balasse et al., 2013), sheep births occurred over approximately three months. The first results obtained at Borduşani-Popină are consistent with this range (Balasse, oral communication 2012). For modern breeds, the observed ranges are shorter (e.g., Digard, 1981; Deniz \& Payne, 1982; Jones, 2006; Blaise \& Balasse, 2011; Balasse et al., 2012b), but when several years are considered together (as for archaeological samples), data can be spread out over more than two months (e.g., about 3 months in Angora goats: Deniz \& Payne, 1982; about 4 months in Soay sheep: Clutton-Brock 
et al., 2004). As for the season of birth, European Neolithic sheep are likely to be born at the end of the winter and during spring (Blaise \& Balasse, 2011; Balasse et al., 2012a, 2013). Therefore, and as the earliest births are in February for modern unimproved sheep in Romania (Morar \& Pusta, 1999; for other similar examples, see Digard, 1981; Jones, 2006; Blaise \& Balasse, 2011), two possible periods of birth are used in this study: FebruaryMarch-April (hypothesis A) and March-April-May (hypothesis B).

\subsubsection{Process for providing month of death distributions}

For each sheep/goat hemimandible, the estimated age is given in the form of a range (average range: 3.9 months) and three possibilities exist for the month of birth (see above). In order to provide reliable month of death distributions, these uncertainties must be taken into account. To achieve this goal, month of death was recalculated 1000 times, for each of the 110 hemimandibles ( $N=60$ at Hârşova tell; $N=50$ at Borduşani-Popină), from values randomly taken in both the respective age range for each hemimandible and the birth period. We used uniform distributions in both cases and values are expressed in days for age estimates and in month for birth (the same process based on values expressed in days for birth led to the same conclusions). Thus, 1000 simulations, that is 1000 month of death distributions, were obtained per site. The final month of death distribution is established from the mean values (calculated for each month; $\pm 1 \sigma$ ). This was carried out for each of the two hypotheses regarding the period of birth.

\subsubsection{Examining the relationship between $\mathrm{dP} 4$ crown height and age}

The dP4 crown height $(\mathrm{CH})$ was measured following Klein et al. (1983) and is referred to hereafter as $\mathrm{aCH}$ (for anterior lobe), as we also took the posterior lobe measurement $(\mathrm{pCH}$; following Helmer et al., 2005).

To examine the relationship between $\mathrm{dP} 4$ crown height and the age estimated from modern data sets, regressions of crown heights on age were calculated. We followed the approach applied by Fernandez \& Legendre (2003) for a similar context. The best fit curve was determined using the least squares method (that is a minimization of the sum of the squares of the differences between the age estimate and the value provided by the model, i.e. the residuals). Constraints were used to improve the model. In order to take into account the ranges of age estimates (Table 3, see below), we recalculated 1000 times the regression parameters from values taken randomly in the respective age range of each hemimandible. In each proposed model, the parameters used are thus the mean values. For each model, 
the average coefficient of determination $\left(R^{2}\right)$, the mean absolute error (that is the average of the absolute residuals; in months), and the 95 per cent interval for the fitting errors (that is 2 standard deviations from the mean of the residuals) are given.

We also compared the age estimates based on modern data sets with the theoretical formulae provided by Klein et al. (1983) and Klein \& Cruz-Uribe (1983) to estimate age from crown height (these are given in Table 5, see below). Since we chose to let the two parameters of the theoretical formulae (AGEs and $\mathrm{CHo}$ ) vary (with some constraints), the same process as for the regressions was used.

We singled out anterior crown height $(\mathrm{aCH})$ as Klein et al. (1983) based their theoretical formulae on this measurement. For the regression formulae, both $\mathrm{aCH}$ and $\mathrm{pCH}$ were examined. For the parameter $\mathrm{CHo}$ (unworn crown height, i.e., the maximal height) used in regressions and theoretical formulae, we chose a range rather than a fixed value. It varies between the maximum height of unworn crown observed in this sample $(\mathrm{aCH}=13.5 \mathrm{~mm} ; \mathrm{pCH}$ $\geq 16.7 \mathrm{~mm}$ ) and a maximal estimate $(\mathrm{aCH}=15 \mathrm{~mm}$; $\mathrm{pCH}=18 \mathrm{~mm})$ based on Romanian Eneolithic assemblages (about $260 \mathrm{dP} 4$; this study and Bréhard, unpublished) and on French Neolithic assemblages (about 180 dP4; Helmer et al., 2005; Bréhard, 2007; Blaise, 2009; Hanot \& Bréhard, unpublished). As no unworn or slightly worn dP4 is available for goats, we only calculated the theoretical formulae for sheep ( $N=99$ ). The parameter AGEs (age at which the dP4 is shed, i.e. the intercept) is based on Jones' (2006) observations on sheep. We used either the average value (25.5 months) or the age range (22-33 months). The same possibilities were used for the regression formulae intercepts (figures from sheep were chosen as they predominate).

As the two sites studied show similar characteristics (and are found below to show very similar season of death distributions), all hemimandibles were analysed together. Six hemimandibles were subtracted from the sample used for examining month of death distributions (no measurement available for $\mathrm{dP} 4$ ) and six were added to extend the goat sample, although the age range exceeds five months (six to seven months; Table 3; see below). For the regression formulae, sheep and goat hemimandibles are pooled in our sample because one global model must be proposed as the aim would be to provide age estimates to isolated $\mathrm{dP} 4$ for which reliable determination cannot be made (Zeder \& Pilaar, 2010).

\subsection{Fish remains}


Complementary approaches were applied to determine fishing periods. Apart from the Danube shad, all the fish species identified at Hârşova tell and Borduşani-Popină were available more or less all year round. However, more profitable and favourable fishing periods may have existed. To ascertain this, we used biological and ecological characteristics of the fish species identified at Hârşova tell and Borduşani-Popină, based on modern data (Bănărascu, 1964; Ciolac, 2004). The spawning period is an important criterion (e.g., Bartosiewicz, 2007) as adults are less vigilant and most fish seek shallow waters near river banks as well as residual waters for spawning, where they become more visible and can be (more) easily caught. In this fluvial context with spring-early summer floods (Zăvoianu, 1969a), quantities of fish can also be trapped in residual pools when water levels recede and can then be easily fished or simply gathered. This type of case primarily concerns young fish (i.e. inexperienced fish; many of whom hatched and grew up in these residual pools) as most mature individuals leave pools as soon as the water level starts to recede.

Analysis of size distribution can help to establish whether the most profitable and favourable fishing periods were the actual fishing/gathering periods (e.g., Pike-Tay et al., 2004; Bartosiewicz, 2007). The identification of large individuals only (i.e. adults) could suggest fishing during the spawning period, when adults are less vigilant and more easily visible. A great proportion of small individuals would indicate fishing/gathering after the spawning period. Osteometric data are available for several species (Radu, 2011). We selected two of them for this study, the common carp (Cyprinus carpio) and the pikeperch (Sander lucioperca). Both of these species were identified in most of the archaeological structures with fish remains, and osteometric data are available for both sites. Total lengths were estimated from different skeletal parts on the basis of the method described in Radu (2011).

At Hârşova tell, these approaches are compared with the results already obtained from skeletochronology analyses applied on the vertebrae of the aforementioned two species (Radu, 2000; Haită \& Radu, 2003). Vertebrae from these two species are well preserved, due to their large size, and their growth rings are easy to read.

\section{Results}

5.1. Month of death distributions for sheep/goats 
Table 3 provides data for the 110 hemimandibles for which precise age estimates were obtained (Hârşova tell: $\mathrm{N}=60$; Borduşani-Popină: $\mathrm{N}=50$ ). The average age range is 3.9 months (minimum: 1 month; maximum: 5 months).

For sheep ( $N=104)$, one hemimandible is in age class $A$, three in age class $B, 91$ in age class $C$ and nine in age class D (age classes as described by Payne, 1973: 293). Only one hemimandible aged more than 14 months is included (Hva75) because age range increases when $\mathrm{M} 2$ goes beyond stage $2 \mathrm{~A}$. After age class $\mathrm{D}$, the age ranges are always too broad to be used for this study. Age classes $A$ to $D$ represent 65 and 69 per cent of the dental remains (Bréhard \& Bălăşescu, 2012); these figures increase to 73 per cent, at both sites, if the MNE is taken into consideration (Table 2). 76 hemimandibles out of 110 are of stage C6+ (as described by Jones, 2006). The slaughtering peak observed for age class $C$ at Hârşova tell and Borduşani-Popină (42 and 43 per cent of the dental remains; Bréhard \& Bălăşescu, 2012 ) is thus in the second part of the age class. Based on Jones' (2006) observations, this stage $66+$ represents an age of 8 to 13 months. For goats, only six hemimandibles are included in the study, one for age class $B$, four for age class $C$ and one for age class $D$.

Figure 2 shows how data are distributed over the year (Table 4). The first result is that whatever the hypothesis, month of death distributions observed at Hârşova tell and Borduşani-Popină are very similar. The Fisher's exact test indicates that distribution is independent of the site for both hypotheses ( $p$-value=0.9999 and 1).

For both hypotheses, we observe that data are distributed throughout the year but some months are characterized by small numbers of hemimandibles while there is a peak around December (hypothesis A) or January (hypothesis B). Based on one standard deviation from the mean, two groups without overlap can be distinguished in both cases. For hypothesis $A$ (birth period: February to April), the first group includes April to September with a maximum at 4.3 for Hârşova tell and at 4 for Borduşani-Popină (average number of hemimandibles: 1.9 and 1.8). The second group includes November to February with a minimum at 5.1 for Hârşova tell and at 4.3 for Borduşani-Popină (average number of hemimandibles: 9.8 and 7.7). October and March overlap these two groups. For hypothesis B (birth period: March to May), the results are the same but shifted by one month (Figure 2). Whatever the hypothesis and the site, months from the first group are always statistically different from those of the second group (dependent $t$-test for paired samples; Supplementary Material 1).

Based on two standard deviations from the mean (that is 95 per cent of the cases), two distinct groups still exist, but each includes fewer months: the first group comprises five months (May to September or June to October) instead of six, and the second includes two months at Hârşova tell (December-January or January-February) and one month at 
Borduşani-Popină (December or January) instead of four. For both hypotheses, the first group includes more months (whatever the interval used, $1 \sigma$ or $2 \sigma$ ) and above all is much more homogeneous than the second. Statistical equality between months (dependent $t$-test for paired samples; Supplementary Material 1) only exists within the first group at Hârşova tell ( 2 cases) and is much more common in the first group at Borduşani-Popină (six or seven cases compared to one case in the second group). This shows that the first group, which is characterized by sparse data for five months, is very reliable. Most data (more than 80 per cent in average) are distributed outside these five months, with a peak around December or January.

We pointed out that 76 hemimandibles out of 110 are of stage C6+. They are all distributed from November to May (example of hypothesis B), at both sites. None of them can be attributed to the first group. A peak is observed around January and 80 per cent of the data are concentrated over four months (December-March). Thus, the slaughtering peak observed for age class $C$ in both kill-off patterns (see above) results from the recurrent slaughter of animals from late autumn to early spring.

In order to check whether global data analysis masks the existence of different practices in some archaeological structures, we compared three different samples from Hârşova tell (one outer level of a dwelling us3244, area of household refuse C136 and trench C98). Very few data are available ( 3 or 4 hemimandibles per structure/unit) but the very low percentages observed from June to October for the three examples (example of hypothesis B; Figure 3) are consistent with our general conclusions.

The distributions observed in Figure 2 document patterns for sheep, given that this species largely predominate the sheep/goat assemblages (Table 2). In order to ascertain whether goats follow these global distributions, Figure 4 provides data for six goat hemimandibles. Although based on small samples, both distributions show that most data (more than 80 per cent) are situated between June and November (example of hypothesis B), which is the opposite of global distributions. This could be explained by different ages-at-death as five out of the six goat hemimandibles are younger or older than the most common stage $(\mathrm{C} 6+; 8-13$ months) observed for sheep hemimandibles (Table 3).

To sum up, although we proceeded with caution regarding age-at-death estimates (ranges encompassing 95 per cent of the modern cases were used to estimate an age) and the period of birth (two hypotheses were considered), the process used (simulations with 1000 random runs) leads to clear conclusions which are the same at both sites. The most 
important result is that very few sheep were slaughtered during five months of the year, in late spring-early autumn or in summer-mid-autumn. Most slaughtering (more than 80 per cent on average) occurred outside these five months, with an early or mid-winter peak. For goats, which comprise a very small minority in sheep/goat assemblages, practices seem to have been distinct. This study only includes age classes $A$ to $D$ but as they represent threequarters of the dental elements (MNE) at both sites, our results are thus a reliable estimate.

\subsection{Relationship between $\mathrm{dP} 4$ crown height and age estimate in sheep/goats}

Figure $5 \mathrm{~A}$ shows the high variability in $\mathrm{dP} 4$ crown height in relation to age. For sheep, for example, stage $6+$ (which lasts 5 months) is characterized by crown heights varying from 8 $\mathrm{mm}$ to $4 \mathrm{~mm}$. This phenomenon can be observed from modern data: the eight lambs with the same age studied by Payne (1985; lambs from Argos) show a range of $4.2 \mathrm{~mm}$. These data also suggest that the rate of attrition is not constant throughout the life of the tooth. For sheep, the rate seems to be quite high during early wear whereas a plateau is clearly observed between (at least) $7 \mathrm{~mm}$ and $5 \mathrm{~mm}$. It is difficult to determine what happens during late wear stages (the last quarter of dP4 life) as no reliable hemimandible over 14 months old is available for sheep (fourteen 'old' hemimandibles of sheep have been added to our sample in Figure 5 to provide an idea of late wear stages, but they are not reliable as the age ranges span 9 months). Based on age estimates from modern data sets, a linear relationship between $\mathrm{dP} 4$ crown height and age is unlikely.

The best-fit curve is based on a natural logarithm function, adapted here to suit our data (Table 5). Contrary to linear regressions, it takes account of the variable rate of wear (Figure 5B). We imposed constraints on intercept as no dP4 exists beyond 33 months according to Jones (2006). This improves the model as it better takes the plateau into consideration (see the first and second examples in Table 5). The earlier the intercept, the better the fitting curve (Table 5). However 22 months is very early if we consider the range and the mean value (25.5 months) observed by Jones (2006). This partly results from the lack of heavily worn dP4 in our sample. This parameter remains to be confirmed. In any event, the coefficient of determination $\left(R^{2}\right)$ remains quite low (from 0.412 to 0.492 ; Table 5 ), which shows that there is no strong correlation between crown height and age in sheep/goat dP4 (Klein et al., 1983 and Pike-Tay et al., 2000 obtained $\mathrm{R}^{2}$ higher than 0.8 for wapiti and caribou molars). The mean absolute errors are acceptable but their high standard deviations indicate marked dispersion from these values (and the differences between the ages estimated from the modern data sets and the values predicted by the models extend over at least 8 months; 95 per cent intervals). The same process based on $\mathrm{pCH}$ instead of aCH 
provides similar results (although a little less satisfactory; two examples are given in Table 5). In this sample, the lobe is not a determining factor. Finally, models based on a polynomial regression (following Pike-Tay et al., 2000 and Fernandez \& Legendre, 2003) did not yield better results.

This approach includes both sheep and goat dP4 (for the reasons expounded in subsection 4.1.5), which may hamper correlation. However, the same process based on sheep dP4 only does not provide a better correlation (only the mean absolute error is slightly better; Table 5). The variability in $\mathrm{dP} 4$ crown height relative to age is definitely too high.

Figure 6 compares the age estimates based on modern data sets with the age estimates calculated from the theoretical formulae proposed by Klein et al. (1983; the formulae are in Table 5). The linear formula provides very low coefficients of determination $\left(R^{2}=-2.391\right.$ or 0.349, for sheep) and high mean absolute errors (Table 5). Quadratically-derived age estimates (QCHM) match our data better, but the coefficients of determination remain very low $\left(R^{2}=0.179\right.$ or 0.213 , for sheep; Table 5). Figure $6 B$ indicates that the $Q C H M$, when compared to age estimates based on modern data sets, underage young individuals (65 per cent of global underestimation; Table 5). Gifford-Gonzalez (1991: Figure 4.10.) observed the same tendencies in bison molars. This suggests that the QCHM is not appropriate for sheep/goat dP4.

In conclusion, based on age estimates from modern data sets, no strong correlation exists between crown height and age in sheep/goat dP4, and the relationship is likely to be curvilinear, rather than linear. A large sample of specimens of known age, including a substantial number of unworn and heavily worn $\mathrm{dP} 4$, would be necessary to definitively assess this relationship, and determine whether $\mathrm{dP} 4$ crown height can be used to estimate age accurately in sheep/goats (with refined QCHM or other nonlinear formulae).

\subsection{Fishing seasons}

Almost all the known fish species from prehistoric sites in south-eastern Romania have been identified at Hârşova tell and Borduşani-Popină (Table 6; Bălăşescu et al., 2005). The latter contains fewer species but this may result from sample size as the fish assemblage is much smaller than at Hârşova tell (Table 6).

Fishing activities were possible all year round in the Danube River, but given that most fish are not active during the cold season (winter stasis) and are thus less visible, this is clearly 
not the most favourable period. Table 6 shows the spawning periods for 19 fish taxa. Spawning occurs mainly between March and June and the peak is clearly in April-May. This period coincides with the spring-early summer floods, which start in March and culminate in June in this part of the Danube River (Zăvoianu, 1969a). Many species (such as cyprinids, which represent more than half of the fish remains; Table 6) take advantage of flooded areas to reproduce. As adult fish are less vigilant and more easily visible during the reproduction period (most cyprinids are in shoals for reproduction and they seek out shallow waters), spring-early summer was clearly a profitable and favourable period for fishing. The presence of shad could provide strong evidence of spring fishing as this anadromous species is only present in the Danube River between March and June (Ciolac, 2004), but the sparse remains identified at Hârşova tell (Table 6) render this proposition somewhat tenuous.

The water level recedes during summer and early autumn (the Danube River reaches its lowest level in September-October; Zăvoianu, 1969b), creating residual pools in the floodplains where some fish, especially young specimens born during spring, can be trapped and then easily gathered/fished. Summer-early autumn was thus another period conducive to fishing activities.

The next step is to examine whether size distributions and skeletochronology results provide evidence that fishing activities primarily occurred during these periods. Size distributions for the common carp (Figure 7; Table 7) show distinct strategies according to the site. At Borduşani-Popină, 62 per cent of the individuals are under the limit proposed for sexually mature animals (about $300 \mathrm{~mm}$; Ciolac, 2004) whereas 90 per cent are above this limit at Hârşova tell (a Chi-square test confirms that size distribution is dependent of the site: $\left.X^{2}=192.9 ; d f=10 ; p=4.897 E-36\right)$. The first distribution is similar to a catastrophic profile in which small individuals represent the majority of the dead fish (see the example of lake poisoning in Bartosiewicz, 2007: Figure 20.4). Given that the common carp spawns in flooded areas in May-June, this size distribution is likely to result from fishing/gathering activities in residual pools formed during summer-early autumn. These natural traps are common in the vicinity of the Borduşani-Popină site. At Hârşova tell, size distribution suggests distinct practices. Small fish were caught but the fishing of large individuals, i.e. adults, was the norm. It is possible that the Hârşova inhabitants fished mainly during the spawning period, when adult fish are less vigilant and easily visible. Fishing/gathering also took place after the spawning period, during summer-early autumn, given the presence of small (young) and medium-sized individuals. Even if some fishing/gathering activities took place during times when fish of all sizes were readily available, this selection of large individuals is not unexpected since carp 'is a typical fish of shallow waters, where even its large specimens may be easily caught' (Bartosiewicz, 2007: 387). 
For pikeperch (Figure 7; Table 7), large individuals dominate at both sites (the lower limit proposed for sexually mature fish is about $250 \mathrm{~mm}$ and the range is between 250 and 400 mm; Bănărascu, 1964). The high proportion of individuals over 400 mm (67 per cent at Hârşova tell; Table 7) could indicate that fishing activities took place during the spawning period, from March to May. Adult males are particularly vulnerable during that time as they guard eggs until they hatch. At Hârşova tell, the clear presence of medium-sized individuals (200-350 mm) suggests that fishing could also have occurred during the second part of the warm period. Fish between 200 and $250 \mathrm{~mm}$ for instance (i.e. individuals in their second year of life) could have been trapped in residual pools or in small lakes which dry up during summer-early autumn and contain large quantities of small cyprinids, their favourite prey. They could then have been fished/gathered at the same time as carp, during summer-early autumn. Finally, unlike carp, small pikeperch (less than $150 \mathrm{~mm}$, representing specimens under a year old) are absent (this is not due to differential collection as $4 \mathrm{~mm}$ sieves were used at both sites). This can be explained by the fact that unlike carp, pikeperch do not spawn in shallow waters, but in large lakes or quite deep branches of the Danube River that seldom dry up. Opportunities to catch young pikeperch are thus less widespread than for young carp. At Borduşani-Popină, this interpretation needs to be confirmed with a larger sample.

At Hârşova tell, the use of skeletochronology techniques, applied to common carp and pikeperch vertebrae ( $\mathrm{N}=2162$; see sections 3. and 4.2.), showed that fishing activities occurred throughout the year (Radu, 2000; Haită \& Radu, 2003). However, winter was only identified for pikeperch, in one of the two studied assemblages and records a very low frequency (less than 4 per cent; Haită and Radu, 2003). Winter catching was thus rare. Although autumn and, to a lesser extent, spring fishing is apparent, at least half of the data indicate summer catching in both assemblages. Whatever the species, there thus appears to have been a main catching season. For both these species, the actual fishing/gathering seasons coincide with the most favourable and profitable fishing periods.

\section{Discussion}

At Hârşova tell, we demonstrated that the most favourable and profitable periods for fishing for two fish species (from spring to early autumn) were the actual fishing/gathering seasons. Pikeperch and the common carp are representative of the 19 taxa identified if we consider the spawning period, and they represent quite distinct behaviour. Therefore, results from 
these two species can reasonably be extrapolated to the others. Although it is very likely that fish catching took place primarily from spring to early autumn, summer was probably not the main fishing season for all the fish species (it is possible that the proportion of summer to autumn or spring would be reversed for some species). Such evidence is not available at Borduşani-Popină but the size distribution for the common carp points to fishing/gathering activities during summer-early autumn. As fish species are the same as at Hârşova tell, it is probable that the inhabitants also took advantage of the period from spring to early autumn. However, the main fishing season could have varied.

Bivalves were also readily available sources of animal protein, considering the location of both tell sites. Bivalve remains are abundant at both sites, especially the painter's mussel and swollen river mussel (Bălăşescu et al., 2005; Radu, 2011). At Hârşova tell, for example, two stratigraphic units from the area of household refuse C521 (structure C521 represents $24.7 \mathrm{~m}^{2}$ and $0.6 \mathrm{~m}$ in height and comprises more than 600 stratigraphic units) yielded about $500 \mathrm{~kg}$ of bivalve remains (Radu, 2011). Experiments conducted in the Danube River, close to the archaeological site of Hârşova tell, showed that such large amounts of bivalve could only be gathered during summer-early autumn, when the water level is low (Bălăşescu \& Radu, 2004; Radu, 2011).

Conversely, we showed that sheep slaughtering seldom occurred during five months of the year, namely late spring-early autumn or summer-mid-autumn (according to the birth period). Most slaughtering (more than 80 per cent on average) occurred outside these five months, centred on an early or mid-winter peak. For both fish and sheep, several archaeological structures show the same tendencies, which suggests that these strategies were maintained for a number of years (or decades?). Thus, it is very likely that seasonal and complementary food supply strategies existed at Hârşova tell and Borduşani-Popină. Although sheep/goats were not the only mammals raised at these sites, and the situation was doubtlessly more complicated, they do represent the main domestic species at Hârşova tell (in relative frequencies, from NISP). For the time being, season of death distributions cannot be provided for domestic cattle and pig (see introduction).

For domestic species in the European Neolithic, few studies examine season/month of death distribution, partly for the reasons expounded in the introduction. A study based on a different method (dental growth mark analysis), conducted at an Early Neolithic site in Hungary, shows similar results (Pike-Tay et al., 2004). No deaths were identified from late spring to early autumn and the 23 specimens (with a predominance of sheep) were distributed from late autumn to spring. This corroborates the likelihood of the strategies observed at Hârşova tell and Borduşani-Popină. Fishing also played an economic role at this Hungarian site, like 
at the Romanian tells, and pike size distribution points to late spring/early summer catching activities (Pike-Tay et al., 2004; Bartosiewicz, 2007).

Did the strategies observed at Hârşova tell and Borduşani-Popină directly result from wild resource availability (tell inhabitants would have taken advantage of the period when fishing and gathering activities were the most profitable, from spring to early autumn, and would have kept small livestock for the "bad" period) or did other factors come into play? Given the birth period, lamb slaughter as early as the summer would not have been profitable in terms of carcass weight. Waiting until late autumn would allow offspring to benefit from the abundant late spring-early summer food and from the new early autumn grass, and thus to obtain a higher meat yield. The succession of activities observed may result from the fact that the tell inhabitants maximised both wild resources and their flocks. The hypothesis that sheep herds were not kept at the sites during the warm period but were brought elsewhere, to more advantageous summer grazing grounds for instance, should also be considered. It is also possible that the cull of some of the oldest lambs was sometimes related to the availability of late winter/early spring feed. Indeed, this is a decisive period in herd management as grass growth can be delayed in case of prolonged winter conditions at a time when winter fodder stocks may be depleted. These propositions are not mutually exclusive.

Seasonal food supply strategies do not necessarily imply that fish and sheep meat consumption followed the same pattern. But it is difficult to demonstrate the existence of deferred consumption from archaeological data. Nonetheless, following the delicate excavation of an area of household refuse (C521) at Hârşova tell, deferred fish intake was proposed. This archaeological structure is the result of a succession of 118 stratigraphic sequences, the formation of which began during the warm season and ended during another warm season (Popovici et al., 2000; Tomescu et al., 2003). Skeletochronology analyses were applied on fish vertebrae from these sequences. The fact that spring, summer and fall seasons were identified in the same sequence several times along the stratigraphic profile may be evidence for deferred fish consumption (Radu, 2000, 2011). However, it is not possible to gauge whether or not this practice was frequent.

Lastly, our results back up the hypothesis of a permanent occupation at both sites. The succession of activities indicates that some inhabitants were present at the sites throughout the year. This corroborates findings from previous studies (Popovici et al., 2000, 2001; Marinescu-Bîlcu, 2001; Haită \& Radu, 2003). However, given the high variability within the Gumelnița tell sites (e.g., Bréhard \& Bălăşescu, 2012), it would be unwise to extend this proposition of permanent occupation to other tell sites. 
Previously observed similarities between the kill-off patterns established for sheep at four Gumelnița tell sites with distinct archaeological characteristics raised the question of a certain standardisation of husbandry practices during the Gumelnița period (Bréhard \& Bălăşescu, 2012). Besides this first common feature, Hârşova tell and Borduşani-Popină also show very similar month of death distributions for sheep and pig mortality profiles (Tresset, Bălăşescu \& Horard-Herbin in Frémondeau, 2012). Even though these sites display some common characteristics, such similarities in management strategies are unexpected given that sheep/goats and domestic pigs are not present in the same proportions at each site (at Hârşova tell, sheep/goats represent a quarter of the mammal remains compared to a sixth for pigs whereas these proportions are inversed at Borduşani-Popină). Moreover, although cattle management strategies do not show the same homogeneity, common characteristics can be observed between the two sites (Bréhard \& Bălăşescu, 2012). It is essential to analyse other Eneolithic sites in order to examine whether this homogeneity in the management of domestic herds is specific to these two large tell sites or if a certain standardisation of husbandry practices (affecting some or all domestic species?) during this period is possible. If confirmed, a standardisation of pastoral practices would contrast markedly with the diversity that characterises Late Eneolithic material culture in the East Balkans, but would be somewhat reminiscent of the similarities in settlement organisation that exist between tell sites, especially in north-eastern Bulgaria (Todorova, 1978; Bailey, 2000; Chapman et al., 2006; Ştefan, 2010).

\section{Conclusions}

Based on classical archaeozoological techniques (record of eruption and wear stages and identification to species-level of sheep/goat mandibles), the approach developed here (simulations with 1000 random runs) takes into account uncertainties specific to archaeological data (both the ranges of age-at-death estimates and the existence of different possibilities for the month of birth), in order to provide reliable month of death distributions for sheep/goats.

This study also provided the opportunity to test the use of dP4 crown height to estimate precise age-at-death for sheep/goats. Based on age estimates from modern data sets, we showed that no strong correlation exists between crown height and age in sheep/goat dP4, and that the relationship is likely to be curvilinear, rather than linear. A large sample of 
specimens of known age is required to definitively assess this relationship, and determine whether dP4 crown height can be used to estimate age accurately in sheep/goats.

Regarding food (animal protein) supplies, we showed that the existence of seasonal and complementary strategies is very likely at Hârşova tell and Borduşani-Popină. The succession of activities observed may result from the fact that the tell inhabitants maximised both wild resources (they took advantage of the period when fishing and gathering activities were the most profitable, from spring to early autumn) and small livestock exploitation (obtaining a good meat yield from lambs born at the end of the winter and during spring may require waiting until the autumn to slaughter them). This could have coincided with resource availability since it is possible that, for grazing reasons, sheep herds were not kept at the sites during the warm period. The analysis of Eneolithic sites where fishing/gathering activities represent a lesser component of the diet should help to understand the factors influencing the food supply strategies developed by Eneolithic communities.

We also highlighted the homogeneity in the management of domestic herds between the two Eneolithic sites studied. Future research will establish whether this standardisation of husbandry practices is confirmed on a larger scale, by examining, for instance, if season of death distributions for sheep/goats vary according to the type of site (tell, flat settlement), site function or the chronological period (Neolithic, Eneolithic).

\section{Acknowledgments}

SB was funded by a post-doctoral fellowship from the Fyssen foundation. This work was supported by a grant from the Romanian National Authority for Scientific Research, CNCSUEFISCDI (PN-II-ID-PCE-2011-3-0982), and by the ERC Starting Grant SIANHE (GA 202881; dir. M. Balasse). We thank G. Obein for the natural logarithm function he proposed to calculate regressions of $\mathrm{dP} 4$ crown height on age. 


\section{References}

Bailey, D.W. 2000. Balkan Prehistory. Exclusion, Incorporation and Identity. London: Routledge.

Bălăşescu, A., Moise, D. \& Radu, V. 2005. The palaeoeconomy of Gumelniț a communities on the territory of Romania. Cultură ș i civilizaț ie la Dunărea de Jos, XXII: 167-200.

Bălăşescu, A. \& Radu, V. 2004. Omul şi animalele. Strategii şi resurse la comunităţ ile Hamangia şi Boian. Muzeul Național de Istorie a României, Seria Cercetări Pluridisciplinare IX. Târgoviș te: Editura Cetatea de Scaun.

Balasse, M., Bălăşescu, A., Janzen, A., Ughetto-Monfrin J., Mirea, P. \& Andreescu, R. 2013. Early herding at Ma $\square$ gura-Boldul lui Mos $\square$ Iva $\square$ nus $\square$ (early sixth millennium BC, Romania): environments and seasonality from stable isotope analysis. European Journal of Archaeology, 16(2): 221-46.

Balasse, M., Boury, L., Ughetto-Monfrin, J. \& Tresset, A. 2012a. Stable isotope insights $(\delta 180, \delta 13 \mathrm{C})$ into cattle and sheep husbandry at Bercy (Paris, France, 4th millennium BC): birth seasonality and winter leaf foddering. Environmental Archaeology, 17(1): 29-44.

Balasse, M., Obein, G., Ughetto, J. \& Mainland, I. 2012b. Investigating seasonality and season of birth in past herds herds: A reference set of sheep enamel stable oxygen isotope ratios. Archaeometry, 54(2): 349-68.

Balasse, M. \& Tresset, A. 2007. Environmental constraints on the reproductive activity of domestic sheep and cattle: what latitude for the herder? Anthropozoologica, 42(2): 71-88.

Bănărescu, P. 1964. Fauna Republicii Populare Romîne, Pisces - Osteichthyes (peşti ganoizi şi osoşi). Bucureşti: Editura Academiei R.S.R.

Bartosiewicz, L. 2007. Fish remains. In: A. Whittle, ed. The Early Neolithic on the great Hungarian plain. Investigations of the Körös culture site of Ecsegfalva 23, County Békés. Varia Archaeologica Hungarica XXI. Budapest: Academiae Scientiarum Hungaricae, pp. 377-94.

Blaise, E. 2009. Economie animale et gestion des troupeaux au Néolithique final en Provence : approche archéozoologique et contribution des analyses isotopiques de l'émail dentaire. Unpublished PhD Thesis, Université de Provence, Faculté des Lettres et Sciences Humaines, Aix-en-Provence. 
Blaise, E. \& Balasse, M. 2011. Seasonality and season of birth of modern and late Neolithic sheep from south-eastern France using tooth enamel $\delta 180$ analysis. Journal of Archaeological Science, 38(11): 3085-93.

Bréhard, S. 2007. Contribution archéozoologique à la connaissance de la fonction des grands sites de terrasse du Chasséen récent (début du 4e millénaire avant J.-C.) de la moyenne vallée du Rhône, dans leur contexte de Méditerranée nord-occidentale.

Unpublished PhD Thesis, Muséum national d'Histoire naturelle, Paris.

Bréhard, S. \& Bălăşescu, A. 2012. What's behind the tell phenomenon? An archaeozoological approach of Eneolithic sites in Romania. Journal of Archaeological Science, 39: 3167-83.

Chapman, J. 2010. Houses, Households, villages, and Proto-Cities in southeastern Europe. In: D.W. Anthony, ed. The Lost World of Old Europe: The Danube Valley, 5000-3500 BC. New York: The Institute for the Study of the Ancient World. Princeton and Oxford: Princeton University Press, pp. 74-89.

Chapman, J., Higham, T., Slavchev, V., Gaydarska, B. \& Honch, N. 2006. The social context of the emergence, development and abandonment of the Varna cemetery, Bulgaria. European Journal of Archaeology, 9(2-3): 159-83.

Ciolac, A. 2004. Migration of fishes in Romanian Danube River. Applied ecology and environmental research, 2(1): 143-63.

Clutton-Brock, T. \& Pemberton, J. 2004. Soay Sheep. Dynamics and Selection in an Island Population. Cambridge: Cambridge University Press.

Deniz, E. \& Payne, S. 1982. Eruption and wear in the mandibular dentition as a guide to ageing Turkish Angora goats. In: B. Wilson, C. Grigson \& S. Payne, eds. Ageing and sexing animal bones from archaeological sites. BAR International Series 109. Oxford:

Archaeopress, pp. 155-205.

Digard, J.-P. 1981. Techniques des nomades Baxtyâri d'Iran. Cambridge: Cambridge University Press. Paris: Maison des Sciences de l'Homme.

Ducos, P. 1968. L'origine des animaux domestiques en Palestine. Publications de l'Institut de Préhistoire de l'Université de Bordeaux 6. Paris: Editions Masson.

Ellis, L. 1984. The Cucuteni-Tripolye culture: Study in technology and the origins of complex society. BAR International Series 217. Oxford: Archaeopress. 
Ervynck, A. 2005. Detecting the seasonal slaughtering of domestic mammals: inferences from the detailed recording of tooth eruption and wear. Environmental Archaeology, 10: 15369.

Ewbank, J.M., Phillipson, D.W. \& Whitehouse, R.D. 1964. Sheep in the Iron Age: a method of study. Proceedings of the Prehistoric Society, 30: 423-26.

Fernandez, P. \& Legendre, S. 2003. Mortality curves for horses from the Middle Palaeolithic site of Bau de l'Aubesier (Vaucluse, France): methodological, palaeo-ethnological, and palaeo-ecological approaches. Journal of Archaeological Science, 30: 1577-98.

Frankel, D., Webb, J.M. \& Pike-Tay, A. 2013. Seasonality and Site Function in Chalcolithic Cyprus. European Journal of Archaeology, 16(1): 94-115.

Frémondeau, D. 2012. Rythmes saisonniers des élevages porcins archéologiques : propositions pour un protocole d'analyse isotopique. Unpublished PhD thesis, Muséum national d'Histoire naturelle, Paris.

Gifford-Gonzales, D. 1991. Examining and Refining the Quadratic Crown Height Method of Age Estimation. In: M.C. Stiner, ed. Human Predators and Prey Mortality. Boulder, San Francisco, Oxford: Westview Press, pp. 41-78.

Gillis, R., Bréhard, S., Bălăşescu, A., Ughetto-Monfrin, J., Popovici, D., Vigne, J.-D. \& Balasse, M. 2013. Sophisticated cattle dairy husbandry at Borduşani-Popină (Romania, 5th mill $\mathrm{BC}$ ): the evidence from complementary analysis of mortality profiles and stable isotopes. World Archaeology, DOI: 10.1080/00438243.2013.820652.

Gillis, R., Chaix, L. \& Vigne J.-D. 2011. An assessment of morphological criteria for discriminating sheep and goat mandibles on a large prehistoric archaeological assemblage (Kerma, Sudan). Journal of Archaeological Science, 38: 2324-39.

Guilaine, J. ed. 2007. Le Chalcolithique et la construction des inégalités. Tome 1, Le continent européen. Paris: Éditions Errance.

Haită, C. 2012. Micromorphological analysis of anthropic sequences from tell settlements in Muntenia and Dobrogea (southern Romania). In: V. Cotiuga \& S. Caliniuc, eds. Interdisciplinarity Research in Archaeology. BAR International Series 2433. Oxford: Archaeopress, pp. 37-44. 
Haită, C. \& Radu, V. 2003. Les zones de rejets menageres de la culture Gumelnița : témoins dans l'évolution chrono-stratigraphique des tells. Etude micromorphologique et archéoichthyologique sur le tell d'Hârşova (Dep. Constanța). Cercetări Arheologice, XII: 387-403.

Halstead, P. 2005. Resettling the Neolithic: faunal evidence for seasons of consumption and residence at Neolithic sites in Greece. In: D. Bailey, A. Whittle \& V. Cummings, eds. (un)settling the Neolithic. Oxford: Oxbow Books, pp. 38-50.

Helmer, D., Gourichon, L., Sidi Maamar, H. \& Vigne, J.-D. 2005. L'élevage des caprinés néolithiques dans le sud-est de la France : saisonnalité des abattages, relations entre grottes-bergeries et sites de plein air. Anthropozoologica, 40(1): 167-89.

Jones, G.G. 2006. Tooth Eruption and Wear Observed in Live Sheep from Butser Hill, the Cotswold Farm Park and Five Farms in the Pentland Hills, UK. In: D. Ruscillo, ed. Recent Advances in Ageing and Sexing Animal Bones. Oxford: Oxbow Books, pp. 155-78.

Jones, G.G. \& Sadler, P. 2012. A review of published sources for age at death in cattle. Environmental Archaeology, 17(1): 1-10.

Jones, G.G. \& Sadler, P. 2012. Age at death in cattle: methods, older cattle and known-age reference material. Environmental Archaeology, 17(1): 11-28.

Kasparov, A. 1994. Environmental Conditions and Farming Strategy of Protohistoric Inhabitants of South-Central Asia. Paléorient, 20(2): 143-49.

Klein, R.G., Allwarden, K. \& Wolf, C. 1983. The calculation and interpretation of ungulate age profiles from dental crown heights. In: G. Bailey, ed. Hunter-gatherer economy in Prehistory: an European perspective. Cambridge: Cambridge University Press, pp. 47-57.

Klein, R.G. \& Cruz-Uribe, K. 1983. The computation of ungulate age (mortality) profiles from dental crown heights. Paleobiology, 9: 70-78.

Legge A.J. \& Rowley-Conwy, P.A. 1991. “... Art Made Strong with Bones”: A Review of some Approaches to Osteoarchaeology. International Journal of Osteoarchaeology, 1: 3-15.

Manolakakis, L. 2007. Varna et le Chalcolithique de Bulgarie. In: J. Guilaine, ed. Le Chalcolithique et la construction des inégalités. Tome 1, Le continent européen. Paris: Éditions Errance, pp. 23-46.

Marinescu-Bîlcu, S. 2001. O civilizație necunoscută: Gumelnița. Colecția Patrimoniu Cultural. Bucureşti: cIMeC - Institutul de Memorie Culturală. 
Marinescu-Bîlcu, S. 2002. A few observations on the internal organization of Gumelnița communities on Lake Cătălui islet. Cultură şi Civilizație la Dunărea de Jos, XIX: 149-50.

Milner, N. 2005. Can seasonality studies be used to identify sedentism in the past? In: D. Bailey, A. Whittle \& V. Cummings, eds. (un)settling the Neolithic. Oxford: Oxbow Books, pp. 32-37.

Moise, D. 2000. Etude du matériel ostéologique appartenant aux mammifères découvert dans le Complexe 521 (la zone ménagère) sur le tell néoénéolithique de Hârşova (dép. de Constantza). Cercetări Arheologice, XI(1): 84-111.

Monah, F. 2000. Rapport préliminaire sur les macrorestes végétaux du complexe ménager 521 - le tell énéolithique Hârș ova (dép. Constanț a). Campagne 1998. Cercetări Arheologice, $\mathrm{XI}(1)$ : 66-74.

Morar, R. \& Pusta, D. 1999. Zootehnie specialã, vol. I, Bovine, Ovine, Caprine, Cabaline. Cluj-Napoca: Editura Relief.

O'Connor, T.P. 1998. On the difficulty of Detecting Seasonal Slaughtering of Sheep.

Environmental Archaeology, 3: 5-11.

Payne, S. 1973. Kill-off patterns in sheep and goats: the mandibles from Asvan Kale. Anatolian Studies, 23: 281-303.

Payne, S. 1985. Morphological distinctions between the mandibular teeth of young sheep, Ovis and goats, Capra. Journal of Archaeological Science, 12: 139-47.

Payne, S. 1987. Reference codes for wear states in the mandibular cheek teeth of sheep and goats. Journal of Archaeological Science, 14: 609-14.

Pike-Tay, A., Bartosiewicz, L., Gal, E. \& Whittle, A. 2004. Body Part Representation and Seasonality: Sheep/Goat, Bird and Fish Remains from Early Neolithic Ecsegfalva 23, SE Hungary. Journal of Taphonomy, 2(4): 221-46.

Pike-Tay, A., Morcomb, C.A. \& O'Farrell M. 2000. Reconsidering the Quadratic Crown Height Method of age estimation for Rangifer from archaeological sites. Archaeozoologia, XI: 14574.

Popovici, D. 2010. Copper Age Traditions North of the Danube River. In: D.W. Anthony, ed. The Lost World of Old Europe: The Danube Valley, 5000-3500 BC. New York: The Institute for the Study of the Ancient World. Princeton and Oxford: Princeton University Press, pp. 90111. 
Popovici, D., Haită, C., Bălăşescu, A., Radu, V., Vlad, F., Tomescu, J. 2003. Archaeological pluridisciplinary researches at Borduș ani-Popina. Muzeul Naț ional de Istorie a României. Seria Cercetări Pluridisciplinare VI. Târgoviș te: Editura Cetatea de Scaun.

Popovici, D., Randoin, B. \& Rialland, Y. 2001. Le tell néolithique et chalcolithique d'Hârşova (Roumanie). In: J. Guilaine, ed. Communautés villageoises du Proche-Orient à l'Atlantique (8000-2000 avant notre ère). Paris: Éditions Errance, pp. 119-52.

Popovici, D., Randoin, B., Rialland, Y., Voinea, V., Vlad, F., Bem, C., Bem, C. \& Haită, G. 2000. Les recherches archéologiques du tell de Hârşova (dép. de Constanța) 1997-1998. Cercetări Arheologice, XI(1): 13-123.

Radu, V. 2000. Sur la durée d'utilisation d'une zone de rejets ménagers appartenant à la culture Gumelnita A2 du tell d'Hârsova. Etude archéologique préliminaire. Cercetãri Arheologice, XI(1): 75-83.

Radu, V. 2011. Le Néolithique de la Roumanie Méridionale : Exploitation des ressources aquatiques dans les cultures Boian et Gumelnița. Sarrebruck: Editions Universitaires Européennes.

Randoin, B., Popovici, D. \& Rialland, Y. 2000. Metoda de săpătură şi înregistrarea datelor stratigrafice într-un sit pluristratificat : tell-ul neoeneolitic de la Hârşova. Cercetări Arheologice, XI(1): 199-234.

Renfrew, C. 1978. Varna and the social context of early metallurgy. Antiquity, 52: 199-203. Rowley-Conwy, P. 1993. Season and reason: the case for a regional interpretation of Mesolithic settlement patterns. In: G.L. Peterkin, H. Bricker \& P. Mellars, eds. Hunting and animal exploitation in the later Paleolithic and Mesolithic Eurasia. Archaeological Papers of the American Anthropological Association 4, pp. 179-88.

Slavchev, V. ed. 2008. The Varna Eneolithic necropolis and problems of Prehistory in southeast Europe. Studia in memoriam Ivani Ivanov. Acta Musei Varnaensis VI. BapHa: Musei Varnaensis.

Ştefan, C.E. 2010. Settlement types and enclosures in the Gumelnița culture. Târgovişte: Editura Cetatea de Scaun.

Stuiver, M. \& Reimer, P.J. 1993, Extended 14C data base and revised CALIB 3.0 14C age calibration program. Radiocarbon, 35: 215-30. 
Todorova, H. 1978. The Eneolithic Period in Bulgaria in the Fifth Millennium B.C. BAR International Series 49. Oxford: Archaeopress.

Tomescu, A.M.F., Radu, V. \& Moise, D. 2003. High Resolution Stratigraphic Distribution of Coprolites within Eneolithic Middens, a Case Study: Hârsova-Tell (Constanta County, Southeast Romania). Environmental Archaeology, 8: 97-109.

Twiss, K.C. 2008. An Assessment of the Archaeological Applicability of Faunal Ageing Methods Based on Dental Wear. International Journal of Osteoarchaeology, 18: 329-351.

Zavoianu, I. 1969a. Viiturile si inundabilitatea. In: Geografia Văii Dunării Româneşti. Bucureşti: Editura Academiei R.S.R., p. 102.

Zavoianu, I. 1969b. Debitele lichide. In: Geografia Văii Dunării Româneşti. Bucureşti: Editura Academiei R.S.R., pp. 99-100.

Zeder, M.A. \& Pilaar, S.E. 2010. Assessing the reliability of criteria used to identify mandibles and mandibular teeth in sheep, Ovis, and goats, Capra. Journal of Archaeological Science, 37(2): 225-42. 


\section{TABLES with captions}

Table 1. Radiocarbon dates for the Gumelnița occupation (phase A2) of Borduşani-Popină. They were calibrated using Calib Rev 6.0 (Stuiver and Reimer, 1993).

$\begin{array}{lllll}\text { Lab no. } & \text { Date BP } & 2 \sigma \text { calibrated age (cal BC) } & \text { Material (genus) } & \text { Context } \\ \text { Poz-51269 } & 5445 \pm 35 & 4350-4242 & \text { Quercus } & \text { SL31 } \\ \text { Poz-51284 } & 5590 \pm 40 & 4494-4350 & \text { Hordeum } & \text { C394, SU7028 }\end{array}$

Table 2. Available samples and species-level identification for sheep/goat mandibles and lower teeth with broad age estimate at Hârşova tell and Borduşani-Popină (Gumelnița A2). See the text (4.1.) for explanation of the methodology. Ovis: Ovis aries. NISP: number of identified specimens. MNE: minimum number of elements.

$\begin{array}{lccccc}\text { Site } & \text { NISP } & \text { NISP species-level } & \begin{array}{c}\text { \% Ovis } \\ \text { (NISP) }\end{array} & \text { MNE } & \begin{array}{c}\text { Complete hemimandibles } \\ \text { of known-species with } \\ \text { narrow age estimate }\end{array} \\ \text { Hârşova tell } & 240 & 139 & 93.5 & 153 & 60 \\ \text { Borduşani-Popină } & 154 & 89 & 88.8 & 113 & 50\end{array}$


Table 3. Dental stage development for the sheep/goat hemimandibles from Hârşova tell (Hva) and Borduşani-Popină (Bord) selected for the study (Gumelnița A2). See the text (4.1.) for explanation of the methodology. The last six specimens are used only for examining the relationship between dP4 crown height and age. Ovis: Ovis aries; Capra: Capra hircus. WS: wear stage from Payne (1987); ES: eruption stage from Ewbank et al. (1964); Jones' stage: stage proposed by Jones (2006) for sheep, after Payne (1973).

\begin{tabular}{|c|c|c|c|c|c|c|c|c|c|c|c|c|c|c|c|c|}
\hline \multirow[t]{2}{*}{$\#$} & \multirow[t]{2}{*}{ Species } & \multirow[t]{2}{*}{$R / L$} & \multicolumn{2}{|c|}{$\mathrm{dP} 4$} & \multicolumn{3}{|c|}{ M1 } & \multicolumn{3}{|c|}{ M2 } & \multicolumn{2}{|c|}{ M3 } & \multirow{2}{*}{$\begin{array}{c}\text { Jones' stage } \\
\text { (Ovis) }\end{array}$} & \multirow{2}{*}{$\begin{array}{l}\text { Estimated } \\
\text { age range }\end{array}$} & \multicolumn{2}{|c|}{$\begin{array}{c}\mathrm{dP} 4 \\
\text { measurements }\end{array}$} \\
\hline & & & WS & Age & ES & WS & Age & ES & WS & Age & ES & Age & & & $\mathrm{aCH}$ & $\mathrm{pCH}$ \\
\hline Hva1 & Ovis & L & 0 & $0-1$ & & & & & & & & & $A(0-1 \mathrm{~m})$ & $0-1$ & & \\
\hline Hva4 & Ovis & $L$ & $4 \mathrm{~A}$ & $1-2$ & V & & $\leq 4$ & & & & & & B (1-4 m) & $1-2$ & 12.5 & \\
\hline Hva5 & Ovis & $L$ & $7 \mathrm{~L}$ & $1-4$ & V & & $\leq 4$ & & & & & & $\mathrm{~B}(1-4 \mathrm{~m})$ & $1-4$ & 11.3 & 15.0 \\
\hline Hva10 & Ovis & $\mathrm{R}$ & $13 \mathrm{~L}$ & $3-9$ & & $2 \mathrm{~A}$ & $3-7$ & & & & & & $\mathrm{C} 1 / 2(3-7 \mathrm{~m})$ & $3-7$ & 9.3 & 15.0 \\
\hline Hva13 & Ovis & $\mathrm{R}$ & $13 \mathrm{~L}$ & $3-9$ & & $2 \mathrm{~A}$ & $3-7$ & & & & & & $\mathrm{C} 1 / 2(3-7 \mathrm{~m})$ & $3-7$ & 8.5 & 13.5 \\
\hline Hva13bis & Ovis & $L$ & $14 \mathrm{~L}$ & $6-21$ & & $2 A$ & $3-7$ & & & & & & $\mathrm{C} 1 / 2(3-7 \mathrm{~m})$ & $3-7$ & 8.6 & 14.0 \\
\hline Hva14 & Ovis & $\mathrm{R}$ & $14 \mathrm{~L}$ & $6-21$ & & $2 \mathrm{~A}$ & $3-7$ & & & & & & $\mathrm{C} 1 / 2(3-7 \mathrm{~m})$ & $3-7$ & 7.9 & 13.0 \\
\hline Hva16 & Ovis & $L$ & $14 \mathrm{~L}$ & $6-21$ & & $3 B$ & $4-9$ & & & & & & $\mathrm{C} 3 / 4(4-9 \mathrm{~m})$ & $4-9$ & 9.2 & 12.4 \\
\hline Hva19bis & Ovis & L & $14 \mathrm{~L}$ & $6-21$ & & $5 \mathrm{~A}$ & $6-10$ & & & & & & $\mathrm{C} 5(6-10 \mathrm{~m})$ & $6-10$ & 8.3 & 12.8 \\
\hline Hva21 & Ovis & L & $15 \mathrm{~K}$ & $9-21$ & & $5 \mathrm{~A}$ & $6-10$ & & & & & & $\mathrm{C} 5(6-10 \mathrm{~m})$ & $6-10$ & 5.8 & 9.1 \\
\hline Hva25 & Ovis & $\mathrm{R}$ & $15 \mathrm{~K}$ & $9-21$ & & $6 \mathrm{~A}$ & $8-11$ & & & & & & $\mathrm{C} 6+(8-13 \mathrm{~m})$ & $8-11$ & 6.9 & 10.0 \\
\hline Hva25bis & Ovis & $\mathrm{L}$ & $14 \mathrm{~L}$ & $6-21$ & & $6 \mathrm{~A}$ & $8-11$ & & & & & & $\mathrm{C} 6+(8-13 \mathrm{~m})$ & $8-11$ & 7.5 & 12.5 \\
\hline Hva26 & Ovis & L & $14 \mathrm{~L}$ & $6-21$ & & $6 \mathrm{~A}$ & $8-11$ & & & & & & $\mathrm{C} 6+(8-13 \mathrm{~m})$ & $8-11$ & 7.8 & 11.0 \\
\hline Hva27 & Ovis & L & $15 \mathrm{~K}$ & $9-21$ & & $6 \mathrm{~A}$ & $8-11$ & & & & & & $\mathrm{C} 6+(8-13 \mathrm{~m})$ & $9-11$ & 7.4 & 10.6 \\
\hline Hva30 & Ovis & L & $16 \mathrm{~L}$ & $10-22$ & & $6 \mathrm{~A}$ & $8-11$ & V & & $\leq 11$ & & & $\mathrm{C} 6+(8-13 \mathrm{~m})$ & $8-11$ & 6.8 & 10.2 \\
\hline Hva31 & Ovis & $\mathrm{L}$ & $16 \mathrm{~L}$ & $10-22$ & & $6 \mathrm{~A}$ & $8-11$ & V & & $\leq 11$ & & & $\mathrm{C} 6+(8-13 \mathrm{~m})$ & $8-11$ & 5.9 & 9.8 \\
\hline Hva31bis & Ovis & $\mathrm{R}$ & $16 \mathrm{~L}$ & $10-22$ & & $6 \mathrm{~A}$ & $8-11$ & V & & $\leq 11$ & & & $\mathrm{C} 6+(8-13 \mathrm{~m})$ & $8-11$ & 6.3 & 10.2 \\
\hline Hva32 & Ovis & $\mathrm{L}$ & $16 \mathrm{~L}$ & $10-22$ & & $6 \mathrm{~A}$ & $8-11$ & & & & & & $\mathrm{C} 6+(8-13 \mathrm{~m})$ & $8-11$ & 6.8 & 10.0 \\
\hline Hva32bis & Ovis & $\mathrm{R}$ & $15 \mathrm{~K}$ & $9-21$ & & $6 \mathrm{~A}$ & $8-11$ & & & & & & $\mathrm{C} 6+(8-13 \mathrm{~m})$ & $8-11$ & 8 & 12.6 \\
\hline Hva33 & Ovis & $\mathrm{L}$ & $16 \mathrm{~L}$ & $10-22$ & & $6 \mathrm{~A}$ & $8-11$ & & & & & & $\mathrm{C} 6+(8-13 \mathrm{~m})$ & $8-11$ & 6.6 & 11.0 \\
\hline Hva34bis & Ovis & $\mathrm{R}$ & $14 \mathrm{~L}$ & $6-21$ & & $6 \mathrm{~A}$ & $8-11$ & & & & & & $\mathrm{C} 6+(8-13 \mathrm{~m})$ & $8-11$ & 7.1 & 10.5 \\
\hline Hva36bis & Ovis & $\mathrm{R}$ & $16 \mathrm{~L}$ & $10-22$ & & $7 \mathrm{~A}$ & $8-13$ & $\mathrm{~V}$ & & $\leq 11$ & & & $\mathrm{C} 6+(8-13 \mathrm{~m})$ & $8-11$ & 5.7 & 8.0 \\
\hline Hva37 & Ovis & $\mathrm{L}$ & $15 \mathrm{~K}$ & $9-21$ & & $7 \mathrm{~A}$ & $8-13$ & $V-E$ & & $\leq 11$ & & & $\mathrm{C} 6+(8-13 \mathrm{~m})$ & $8-11$ & 6.5 & 10.1 \\
\hline Hva37bis & Ovis & $\mathrm{R}$ & $15 \mathrm{~K}$ & $9-21$ & & $7 \mathrm{~A}$ & $8-13$ & $E$ & & $8-13$ & & & $\mathrm{C} 6+(8-13 \mathrm{~m})$ & $8-13$ & 7.5 & 10.5 \\
\hline Hva38 & Ovis & $\mathrm{L}$ & $16 \mathrm{~L}$ & $10-22$ & & $7 \mathrm{~A}$ & $8-13$ & $V-E$ & & $\leq 11$ & & & $\mathrm{C} 6+(8-13 \mathrm{~m})$ & $8-11$ & 6.5 & 8.4 \\
\hline
\end{tabular}




\begin{tabular}{|c|c|c|c|c|c|c|c|c|c|c|c|c|c|}
\hline Hva38bis & Ovis & $\mathrm{R}$ & $17 \mathrm{~L}$ & $11-27$ & $7 A$ & $8-13$ & $\mathrm{E}$ & & $8-13$ & $\mathrm{C} 6+(8-13 \mathrm{~m})$ & $8-13$ & 5.5 & 8.4 \\
\hline Hva39 & Ovis & $\mathrm{L}$ & $17 \mathrm{~L}$ & $11-27$ & $7 A$ & $8-13$ & V-E & & $\leq 11$ & $\mathrm{C} 6+(8-13 \mathrm{~m})$ & $8-11$ & 5.7 & 8.5 \\
\hline Hva40 & Ovis & $\mathrm{L}$ & $15 \mathrm{~K}$ & $9-21$ & $7 \mathrm{~A}$ & 8-13 & & & & $\mathrm{C} 6+(8-13 \mathrm{~m})$ & 8-13 & 6.5 & 10.0 \\
\hline Hva40bis & Ovis & $\mathrm{R}$ & $16 \mathrm{~L}$ & $10-22$ & $7 \mathrm{~A}$ & $8-13$ & $V-E$ & & $\leq 11$ & $\mathrm{C} 6+(8-13 \mathrm{~m})$ & $8-11$ & 5.9 & 9.3 \\
\hline Hva41 & Ovis & $\mathrm{L}$ & $16 \mathrm{~L}$ & $10-22$ & $7 \mathrm{~A}$ & $8-13$ & $\mathrm{E} ?$ & & $8-13$ & $\mathrm{C} 6+(8-13 \mathrm{~m})$ & $8-13$ & 5 & 8.8 \\
\hline Hva41bis & Ovis & $\mathrm{R}$ & $17 \mathrm{~L}$ & $11-27$ & $7 \mathrm{~A}$ & $8-13$ & & & & $\mathrm{C} 6+(8-13 \mathrm{~m})$ & $8-13$ & 5.7 & 9.6 \\
\hline Hva42 & Ovis & L & $15 \mathrm{~K}$ & $9-21$ & $7 \mathrm{~A}$ & $8-13$ & V & & $\leq 11$ & $\mathrm{C} 6+(8-13 \mathrm{~m})$ & $8-11$ & 5.4 & 9.0 \\
\hline Hva43 & Ovis & $\mathrm{L}$ & $16 \mathrm{~L}$ & $10-22$ & $7 \mathrm{~A}$ & $8-13$ & v & & $\leq 11$ & $\mathrm{C} 6+(8-13 \mathrm{~m})$ & $8-11$ & 6 & 9.2 \\
\hline Hva43bis & Ovis & $\mathrm{R}$ & $17 \mathrm{~L}$ & $11-27$ & $7 \mathrm{~A}$ & $8-13$ & $\mathrm{v}$ & & $\leq 11$ & $\mathrm{C} 6+(8-13 \mathrm{~m})$ & $8-11$ & 5 & 7.3 \\
\hline Hva44 & Ovis & $\mathrm{L}$ & $16 \mathrm{~L}$ & $10-22$ & $7 \mathrm{~A}$ & $8-13$ & $V-E$ & & $\leq 11$ & $\mathrm{C} 6+(8-13 \mathrm{~m})$ & $8-11$ & 6.7 & 9.3 \\
\hline Hva44bis & Ovis & $\mathrm{R}$ & $17 \mathrm{~L}$ & $11-27$ & $7 \mathrm{~A}$ & 8-13 & & & & $\mathrm{C} 6+(8-13 \mathrm{~m})$ & 8-13 & 5.4 & 8.0 \\
\hline Hva45 & Ovis & L & $16 \mathrm{~L}$ & $10-22$ & $7 \mathrm{~A}$ & $8-13$ & & & & $\mathrm{C} 6+(8-13 \mathrm{~m})$ & $8-13$ & 6.4 & 10.4 \\
\hline Hva45bis & Ovis & $\mathrm{R}$ & $16 \mathrm{~L}$ & $10-22$ & $7 \mathrm{~A}$ & $8-13$ & & & & $\mathrm{C} 6+(8-13 \mathrm{~m})$ & $8-13$ & 6 & 9.0 \\
\hline Hva46 & Ovis & $\mathrm{L}$ & $16 \mathrm{~L}$ & $10-22$ & $7 \mathrm{~A}$ & $8-13$ & & & & $\mathrm{C} 6+(8-13 \mathrm{~m})$ & $8-13$ & 5 & 8.3 \\
\hline Hva46bis & Ovis & $\mathrm{R}$ & $16 \mathrm{~L}$ & $10-22$ & $7 \mathrm{~A}$ & $8-13$ & & & & $\mathrm{C} 6+(8-13 \mathrm{~m})$ & $8-13$ & 5 & 8.6 \\
\hline Hva47bis & Ovis & $\mathrm{R}$ & $15 \mathrm{~K}$ & $9-21$ & $7 \mathrm{~A}$ & $8-13$ & $V-E$ & & $\leq 11$ & $\mathrm{C} 6+(8-13 \mathrm{~m})$ & $8-11$ & 7.4 & 10.3 \\
\hline Hva48bis & Ovis & $\mathrm{R}$ & $16 \mathrm{~L}$ & $10-22$ & $7 \mathrm{~A}$ & $8-13$ & & & & $\mathrm{C} 6+(8-13 \mathrm{~m})$ & $8-13$ & 7.2 & 10.5 \\
\hline Hva50bis & Ovis & $\mathrm{R}$ & $14 \mathrm{~L}$ & $6-21$ & $8 A$ & $11-27$ & E & & $8-13$ & $\mathrm{C} 6+(8-13 \mathrm{~m})$ & $8-13$ & 6.8 & 10.1 \\
\hline Hva50 & Ovis & L & $15 \mathrm{~K}$ & $9-21$ & $7 A-8 A$ & $8-27$ & v & & $\leq 11$ & $\mathrm{C} 6+(8-13 \mathrm{~m})$ & $8-11$ & 6.5 & 9.8 \\
\hline Hva51 & Ovis & $\mathrm{L}$ & $15 \mathrm{~K}$ & $9-21$ & $8 \mathrm{~A}$ & $11-27$ & $\mathrm{~V}$ & & $\leq 11$ & $\mathrm{C} 6+(8-13 \mathrm{~m})$ & $8-11$ & 7.2 & 9.6 \\
\hline Hva52 & Ovis & L & $16 \mathrm{~L}$ & $10-22$ & $8 \mathrm{~A}$ & $11-27$ & $V-E$ & & $\leq 11$ & $\mathrm{C} 6+(8-13 \mathrm{~m})$ & $8-11$ & 5.8 & 9.5 \\
\hline Hva52bis & Ovis & $\mathrm{R}$ & $15 \mathrm{~K}$ & $9-21$ & $8 \mathrm{~A}$ & $11-27$ & $V-E$ & & $\leq 11$ & $\mathrm{C} 6+(8-13 \mathrm{~m})$ & $8-11$ & 6.3 & 9.8 \\
\hline Hva53 & Ovis & $\mathrm{L}$ & $19 \mathrm{M}$ & $11-30$ & $8 \mathrm{~A}$ & $11-27$ & $\mathrm{E}$ & & $8-13$ & $\mathrm{C} 6+(8-13 \mathrm{~m})$ & $8-13$ & 4 & 6.3 \\
\hline Hva54 & Ovis & $\mathrm{L}$ & $16 \mathrm{~L}$ & $10-22$ & $8 \mathrm{~A}$ & $11-27$ & $E-1 / 2$ & & $8-13$ & $\mathrm{C} 6+(8-13 \mathrm{~m})$ & $8-13$ & 6.4 & 9.5 \\
\hline Hva55 & Ovis & $\mathrm{L}$ & $17 \mathrm{~L}$ & $11-27$ & $8 \mathrm{~A}$ & $11-27$ & E & & $8-13$ & $\mathrm{C} 6+(8-13 \mathrm{~m})$ & $8-13$ & 5.6 & 8.8 \\
\hline Hva56 & Ovis & $\mathrm{L}$ & $17 \mathrm{~L}$ & $11-27$ & $8 \mathrm{~A}$ & $11-27$ & $E-1 / 2$ & & $8-13$ & $\mathrm{C} 6+(8-13 \mathrm{~m})$ & $8-13$ & 6 & 8.3 \\
\hline Hva57 & Ovis & $\mathrm{R}$ & $16 \mathrm{~L}$ & $10-22$ & $9 \mathrm{~A}$ & $11-78$ & $E-1 / 2$ & & $8-13$ & $\mathrm{C} 6+(8-13 \mathrm{~m})$ & $8-13$ & 5.3 & 7.7 \\
\hline Hva58 & Ovis & $\mathrm{R}$ & $16 \mathrm{~L}$ & $10-22$ & $9 A$ & $11-78$ & & $2 \mathrm{~A}$ & $10-14$ & $\mathrm{D} 1 / 2(10-14 \mathrm{~m})$ & $10-14$ & 5.4 & 8.5 \\
\hline Hva59 & Ovis & $\mathrm{R}$ & 1 & 1 & $8 \mathrm{~B}$ & $11-27$ & & $2 \mathrm{~A}$ & $10-14$ & $\mathrm{D} 1 / 2(10-14 \mathrm{~m})$ & $10-14$ & & \\
\hline Hva59bis & Ovis & $\mathrm{L}$ & $18 \mathrm{~L}$ & $11-30$ & $9 A$ & $11-78$ & & $2 \mathrm{~A}$ & $10-14$ & $\mathrm{D} 1 / 2(10-14 \mathrm{~m})$ & $10-14$ & 4.2 & 7.2 \\
\hline
\end{tabular}


Table 3. Continued

\begin{tabular}{|c|c|c|c|c|c|c|c|c|c|c|c|c|c|c|c|c|}
\hline \multirow[t]{2}{*}{$\#$} & \multirow[t]{2}{*}{ Species } & \multirow[t]{2}{*}{$R / L$} & \multicolumn{2}{|l|}{$\mathrm{dP} 4$} & \multicolumn{3}{|c|}{ M1 } & \multicolumn{3}{|c|}{ M2 } & \multicolumn{2}{|c|}{ M3 } & \multirow{2}{*}{$\begin{array}{c}\text { Jones' stage } \\
\text { (Ovis) }\end{array}$} & \multirow{2}{*}{$\begin{array}{l}\text { Estimated } \\
\text { age range }\end{array}$} & \multicolumn{2}{|c|}{$\begin{array}{c}\mathrm{dP} 4 \\
\text { measurements }\end{array}$} \\
\hline & & & WS & Age & ES & WS & Age & ES & WS & Age & ES & Age & & & $\mathrm{aCH}$ & $\mathrm{pCH}$ \\
\hline Hva62 & Ovis & $\mathrm{R}$ & $18 \mathrm{~L}$ & $11-30$ & & $9 A$ & $11-78$ & & $2 A$ & $10-14$ & & & $\mathrm{D} 1 / 2(10-14 \mathrm{~m})$ & $10-14$ & 3.9 & 6.0 \\
\hline Hva75 & Ovis & $L$ & P4 early wear & $\geq 22$ & & $9 \mathrm{~A}$ & $11-78$ & & $7 \mathrm{~A}$ & $14-42$ & $E-U$ & $18-27$ & $(\mathrm{D} 6+(14-27 \mathrm{~m}))$ & $22-27$ & & \\
\hline Hva15 & Capra & L & $15 \mathrm{~K}$ & $3-20$ & & $4 \mathrm{~B}$ & $4.5-7.5$ & & & & & & age class $C$ & $4.5-7.5$ & 6.7 & 8.5 \\
\hline Hva17 & Capra & $\mathrm{R}$ & $15 \mathrm{~K}$ & $3-20$ & & $4 \mathrm{~A}$ & $4.5-7.5$ & & & & & & age class $C$ & $4.5-7.5$ & 6.8 & 9.0 \\
\hline Hva20 & Capra & $\mathrm{R}$ & $14 \mathrm{~L}$ & $3-10$ & & $5 \mathrm{~A}$ & $5-12$ & & & & & & age class $\mathrm{C}$ & $5-10$ & 5.7 & 7.8 \\
\hline Bord4 & Ovis & $\mathrm{L}$ & 13L & $3-9$ & E-U & & $2-5$ & & & & & & $B(1-4 \mathrm{~m})$ & $2-4$ & 11.4 & 16.7 \\
\hline Bord5 & Ovis & L & $15 \mathrm{~K}$ & $9-21$ & $U$ & $2 \mathrm{~A}$ & $3-7$ & & & & & & $\mathrm{C} 1 / 2(3-7 \mathrm{~m})$ & $3-7$ & 8.9 & 12.4 \\
\hline Bord6 & Ovis & $\mathrm{L}$ & $15 \mathrm{~K}$ & $9-21$ & $U$ & $2 \mathrm{~A}$ & $3-7$ & & & & & & $\mathrm{C} 1 / 2(3-7 \mathrm{~m})$ & $3-7$ & 7.2 & 11.1 \\
\hline Bord6bis & Ovis & $\mathrm{R}$ & $15 \mathrm{~K}$ & $9-21$ & $U$ & $2 \mathrm{~A}$ & $3-7$ & & & & & & $\mathrm{C} 1 / 2(3-7 \mathrm{~m})$ & $3-7$ & 8.8 & 12.7 \\
\hline Bord7 & Ovis & $\mathrm{L}$ & $16 \mathrm{~L}$ & $10-22$ & $U_{+}$ & $2 \mathrm{~A}$ & $3-7$ & & & & & & $\mathrm{C} 1 / 2(3-7 \mathrm{~m})$ & $3-7$ & 7.5 & 11.3 \\
\hline Bord10 & Ovis & $\mathrm{R}$ & $15 \mathrm{~K}$ & $9-21$ & & $5 \mathrm{~A}$ & $6-10$ & & & & & & C5 (6-10 m) & $6-10$ & 7.9 & 12 \\
\hline Bord10bis & Ovis & $\mathrm{L}$ & & & & $5 \mathrm{~A}$ & $6-10$ & & & & & & C5 $(6-10 \mathrm{~m})$ & $6-10$ & & \\
\hline Bord11 & Ovis & $\mathrm{R}$ & $15 \mathrm{~K}$ & $9-21$ & & $5 \mathrm{~A}$ & $6-10$ & & & & & & C5 $(6-10 \mathrm{~m})$ & $6-10$ & 7.2 & 10.1 \\
\hline Bord12 & Ovis & $\mathrm{R}$ & $16 \mathrm{~L}$ & $10-22$ & & $5 \mathrm{~A}+$ & $6-10$ & & & & & & C5 (6-10 m) & $6-10$ & 6.6 & 9.5 \\
\hline Bord13 & Ovis & $L$ & $15 \mathrm{~K}$ & $9-21$ & & $6 \mathrm{~A}$ & $8-11$ & V & & $\leq 11$ & & & $\mathrm{C} 6+(8-13 \mathrm{~m})$ & $8-11$ & 5.8 & 9.6 \\
\hline Bord14 & Ovis & $\mathrm{L}$ & $15 \mathrm{~K}$ & $9-21$ & & $6 \mathrm{~A}$ & $8-11$ & v & & $\leq 11$ & & & $\mathrm{C} 6+(8-13 \mathrm{~m})$ & $8-11$ & 6.7 & 10.3 \\
\hline Bord15 & Ovis & $\mathrm{R}$ & $16 \mathrm{~L}$ & $10-22$ & & $7 \mathrm{~A}$ & $8-13$ & V & & $\leq 11$ & & & $\mathrm{C} 6+(8-13 \mathrm{~m})$ & $8-11$ & 6 & 9.7 \\
\hline Bord15bis & Ovis & $L$ & $16 \mathrm{~L}$ & $10-22$ & & $7 \mathrm{~A}$ & $8-13$ & C-V & & $\leq 11$ & & & $\mathrm{C} 6+(8-13 \mathrm{~m})$ & $8-11$ & 5.6 & 9 \\
\hline Bord16 & Ovis & $\mathrm{R}$ & $15 \mathrm{~K}$ & $9-21$ & & $7 \mathrm{~A}$ & $8-13$ & $\mathrm{~V}$ & & $\leq 11$ & & & $\mathrm{C} 6+(8-13 \mathrm{~m})$ & $8-11$ & 6.2 & 8.2 \\
\hline Bord17 & Ovis & $\mathrm{R}$ & $17 \mathrm{~L}$ & $11-27$ & & $7 \mathrm{~A}$ & $8-13$ & $(\mathrm{~V})$ & & $\leq 11$ & & & $\mathrm{C} 6+(8-13 \mathrm{~m})$ & $8-11$ & 5.3 & 8.3 \\
\hline Bord17bis & Ovis & $\mathrm{L}$ & $17 \mathrm{~L}$ & $11-27$ & & $8 \mathrm{~B}$ & $11-27$ & $\mathrm{~V}$ & & $\leq 11$ & & & $\mathrm{C} 6+(8-13 \mathrm{~m})$ & $8-11$ & 5.4 & 7.6 \\
\hline Bord18 & Ovis & $\mathrm{R}$ & $15 \mathrm{~K} / 16 \mathrm{~L}$ & $9-22$ & & $7 \mathrm{~A}$ & $8-13$ & $\mathrm{~V}$ & & $\leq 11$ & & & $\mathrm{C} 6+(8-13 \mathrm{~m})$ & $8-11$ & 6.1 & 9 \\
\hline Bord18bis & Ovis & $\mathrm{L}$ & & & & $7 \mathrm{~A}$ & $8-13$ & $\mathrm{C} / \mathrm{V}$ & & $\leq 11$ & & & $\mathrm{C} 6+(8-13 \mathrm{~m})$ & $8-11$ & & \\
\hline Bord19 & Ovis & $\mathrm{R}$ & 16L/17L & $10-27$ & & $6 \mathrm{~A}$ & $8-11$ & $\mathrm{~V}$ & & $\leq 11$ & & & $\mathrm{C} 6+(8-13 \mathrm{~m})$ & $8-11$ & 6.3 & 9.5 \\
\hline Bord19bis & Ovis & $\mathrm{L}$ & $16 \mathrm{~L} / 17 \mathrm{~L}$ & $10-27$ & & $7 \mathrm{~A}$ & $8-13$ & $E$ & & $8-13$ & & & $\mathrm{C} 6+(8-13 \mathrm{~m})$ & $8-13$ & 5.4 & 7.6 \\
\hline Bord20 & Ovis & $\mathrm{R}$ & $17 \mathrm{~L}$ & $11-27$ & & $7 \mathrm{~A}$ & $8-13$ & $E$ & & $8-13$ & & & $\mathrm{C} 6+(8-13 \mathrm{~m})$ & $8-13$ & 4.8 & 8.7 \\
\hline Bord20bis & Ovis & $\mathrm{L}$ & $14 \mathrm{~L} / 15 \mathrm{~K}$ & $6-21$ & & $7 \mathrm{~A}$ & $8-13$ & & & & & & $\mathrm{C} 6+(8-13 \mathrm{~m})$ & $8-13$ & 7 & 9.6 \\
\hline Bord21 & Ovis & $\mathrm{R}$ & $15 \mathrm{~K}$ & $9-21$ & & $7 \mathrm{~A}$ & $8-13$ & & & & & & $\mathrm{C} 6+(8-13 \mathrm{~m})$ & $8-13$ & 6.5 & 9.7 \\
\hline Bord21bis & Ovis & $\mathrm{L}$ & $15 \mathrm{~K}$ & $9-21$ & & $7 \mathrm{~A}$ & $8-13$ & & & & & & $\mathrm{C} 6+(8-13 \mathrm{~m})$ & $8-13$ & 6.5 & 11.5 \\
\hline
\end{tabular}




\begin{tabular}{|c|c|c|c|c|c|c|c|c|c|c|c|c|c|c|c|c|}
\hline Bord22 & Ovis & $\mathrm{R}$ & $17 \mathrm{~L}$ & $11-27$ & & $7 A$ & $8-13$ & & & & & & $\mathrm{C} 6+(8-13 \mathrm{~m})$ & $8-13$ & 5.4 & 9 \\
\hline Bord22bis & Ovis & $\mathrm{L}$ & $16 \mathrm{~L}$ & $10-22$ & & $7 \mathrm{~A}$ & $8-13$ & & & & & & $\mathrm{C} 6+(8-13 \mathrm{~m})$ & $8-13$ & 5.8 & 8.1 \\
\hline Bord23 & Ovis & $\mathrm{R}$ & $16 \mathrm{~L}$ & $10-22$ & & $7 \mathrm{~A}$ & 8-13 & & & & & & $\mathrm{C} 6+(8-13 \mathrm{~m})$ & 8-13 & 7 & 9.1 \\
\hline Bord23bis & Ovis & $\mathrm{L}$ & $17 \mathrm{~L}$ & $11-27$ & & $7 \mathrm{~A}$ & $8-13$ & $E$ & & $8-13$ & & & $\mathrm{C} 6+(8-13 \mathrm{~m})$ & $8-13$ & 6.3 & 8.6 \\
\hline Bord24 & Ovis & $\mathrm{R}$ & $15 \mathrm{~K}$ & $9-21$ & & $7 \mathrm{~A}$ & $8-13$ & & & & & & $\mathrm{C} 6+(8-13 \mathrm{~m})$ & $8-13$ & & \\
\hline Bord25 & Ovis & $\mathrm{R}$ & $16 \mathrm{~L}$ & $10-22$ & & $7 \mathrm{~A}$ & $8-13$ & $\mathrm{E}$ & & $8-13$ & & & $\mathrm{C} 6+(8-13 \mathrm{~m})$ & $8-13$ & 7.5 & 11.8 \\
\hline Bord26bis & Ovis & L & $17 \mathrm{~L}$ & $11-27$ & & $8 A$ & $11-27$ & $(E)$ & & $8-13$ & & & $\mathrm{C} 6+(8-13 \mathrm{~m})$ & $8-13$ & 4.4 & 5.7 \\
\hline Bord27 & Ovis & $\mathrm{R}$ & $16 \mathrm{~L}$ & $10-22$ & & $8 \mathrm{~A}$ & $11-27$ & $V-E$ & & $\leq 11$ & & & $\mathrm{C} 6+(8-13 \mathrm{~m})$ & $8-11$ & 8 & 12 \\
\hline Bord27bis & Ovis & $\mathrm{L}$ & $15 \mathrm{~K}$ & $9-21$ & & $8 \mathrm{~A}$ & $11-27$ & $V-E$ & & $\leq 11$ & & & $\mathrm{C} 6+(8-13 \mathrm{~m})$ & $8-11$ & 6.5 & 9.7 \\
\hline Bord28 & Ovis & $\mathrm{R}$ & $16 \mathrm{~L}$ & $10-22$ & & $7 \mathrm{~A}$ & 8-13 & E- & & $8-13$ & & & $\mathrm{C} 6+(8-13 \mathrm{~m})$ & $8-13$ & 6.2 & 9.2 \\
\hline Bord28bis & Ovis & $\mathrm{L}$ & $17 \mathrm{~L}$ & $11-27$ & & $8 \mathrm{~A}$ & $11-27$ & E- & & 8-13 & & & $\mathrm{C} 6+(8-13 \mathrm{~m})$ & 8-13 & 5.5 & 8.7 \\
\hline Bord29 & Ovis & $\mathrm{R}$ & $17 \mathrm{~L}$ & $11-27$ & & $8 \mathrm{~A}$ & $11-27$ & $E$ & & $8-13$ & & & $\mathrm{C} 6+(8-13 \mathrm{~m})$ & $8-13$ & 6.1 & 9.8 \\
\hline Bord29bis & Ovis & L & $16 \mathrm{~L}$ & $10-22$ & & $8 \mathrm{~A}$ & $11-27$ & $E$ & & $8-13$ & & & $\mathrm{C} 6+(8-13 \mathrm{~m})$ & $8-13$ & 5.7 & 7.5 \\
\hline Bord30 & Ovis & $\mathrm{R}$ & $17 \mathrm{~L}$ & $11-27$ & & $8 \mathrm{~A}$ & $11-27$ & $V-E$ & & $\leq 11$ & & & $\mathrm{C} 6+(8-13 \mathrm{~m})$ & $8-11$ & 6 & 10 \\
\hline Bord30bis & Ovis & L & 17L & $11-27$ & & $8 \mathrm{~A}$ & $11-27$ & $\mathrm{E}$ & & $8-13$ & & & $\mathrm{C} 6+(8-13 \mathrm{~m})$ & $8-13$ & 5.6 & 9 \\
\hline Bord31 & Ovis & $\mathrm{R}$ & 16L/17L & $10-27$ & & $8 A-9 A$ & $11-66$ & E & & $8-13$ & & & $\mathrm{C} 6+(8-13 \mathrm{~m})$ & $8-13$ & 6.1 & 8.1 \\
\hline Bord31bis & Ovis & $\mathrm{L}$ & $16 \mathrm{~L} / 17 \mathrm{~L}$ & $10-27$ & & $8 \mathrm{~A}$ & $11-27$ & E & & $8-13$ & & & $\mathrm{C} 6+(8-13 \mathrm{~m})$ & $8-13$ & 5.8 & 8 \\
\hline Bord32bis & Ovis & $\mathrm{L}$ & $17 \mathrm{~L}$ & $11-27$ & & $9 \mathrm{~A}$ & $11-78$ & $E$ & & $8-13$ & & & $\mathrm{C} 6+(8-13 \mathrm{~m})$ & $8-13$ & 4.8 & 6.6 \\
\hline Bord33bis & Ovis & $\mathrm{L}$ & $17 \mathrm{~L}$ & $11-27$ & & $8 \mathrm{~A}$ & $11-27$ & $\geq E$ & & $8-13$ & & & $\mathrm{C} 6+(8-13 \mathrm{~m})$ & $8-13$ & 5.3 & 8 \\
\hline Bord39bis & Ovis & L & $18 \mathrm{~L}$ & $11-30$ & & $9 A$ & $11-78$ & $U$ & $2 \mathrm{~A}$ & $10-14$ & & & $\mathrm{D} 1 / 2(10-14 \mathrm{~m})$ & $10-14$ & 4 & \\
\hline Bord41 & Ovis & $\mathrm{R}$ & $22 \mathrm{~L}$ & $14-30$ & & $8 \mathrm{~A}$ & $11-27$ & & $2 \mathrm{~A}$ & $10-14$ & & & $\mathrm{D} 1 / 2(10-14 \mathrm{~m})$ & $10-14$ & 3.6 & 5.5 \\
\hline Bord41bis & Ovis & $\mathrm{L}$ & $22 \mathrm{~L}$ & $14-30$ & & $8 \mathrm{~A}$ & $11-27$ & & $2 A$ & $10-14$ & & & $\mathrm{D} 1 / 2(10-14 \mathrm{~m})$ & $10-14$ & 3.4 & 5.4 \\
\hline Bord42 & Ovis & $\mathrm{R}$ & 16L/17L & $10-27$ & & $9 A$ & $11-78$ & & $2 A$ & $10-14$ & & & $\mathrm{D} 1 / 2(10-14 \mathrm{~m})$ & $10-14$ & 4.6 & 5.5 \\
\hline Bord3 & Capra & $\mathrm{R}$ & $13 \mathrm{~L}$ & $2-7$ & E- & & $2.5-4.5$ & & & & & & age class B & $2.5-4.5$ & 7.3 & 10.7 \\
\hline Bord8 & Capra & $\mathrm{R}$ & $15 \mathrm{~K}$ & $3-20$ & $U$ & $4 \mathrm{~A}$ & $4.5-7.5$ & & & & & & age class $\mathrm{C}$ & $4.5-7.5$ & 8 & 10.6 \\
\hline Bord40 & Capra & L & $22 \mathrm{~L}$ & $12-25$ & & $9 A$ & $13-50$ & & $\leq 2 \mathrm{~A}$ & $10.5-18$ & & & age class $\mathrm{D}$ & $13-18$ & 2.4 & 4.8 \\
\hline Hva18 & Capra & $\mathrm{R}$ & $15 \mathrm{~K}$ & $3-20$ & & $4 A-5 A$ & $4.5-12$ & & & & & & age class $C$ & $4.5-12$ & 7.2 & 10.3 \\
\hline Hva64bis & Capra & $\mathrm{L}$ & $21 \mathrm{M}$ & $12-25$ & & $9 \mathrm{~A}$ & $13-50$ & & $4 \mathrm{~A}$ & $12-20$ & $\mathrm{C}$ & $\leq 29$ & age class $\mathrm{D}$ & $13-20$ & 4.8 & 5.5 \\
\hline Hva64 & Capra & $\mathrm{R}$ & $21 \mathrm{M}$ & $12-25$ & & $9 \mathrm{~A}$ & $13-50$ & & $4 \mathrm{~A}$ & $12-20$ & $\leq \mathrm{C}$ & $\leq 29$ & age class $D$ & $13-20$ & 4.8 & 5.3 \\
\hline Bord9 & Capra & $\mathrm{R}$ & $15 \mathrm{~K}$ & $3-20$ & & $5 \mathrm{~A}$ & $5-12$ & & & & & & age class $C$ & $5-12$ & 7.6 & 10 \\
\hline Bord9bis & Capra & $\mathrm{L}$ & $16 \mathrm{~L}$ & $3.5-20$ & & $5 \mathrm{~A}$ & $5-12$ & & & & & & age class $C$ & $5-12$ & 5.9 & 7.4 \\
\hline Bord2 & Ovis & $\mathrm{R}$ & $10 N$ & $3-7$ & & & & & & & & & $\mathrm{~B} / \mathrm{C} 1 / 2(1-7 \mathrm{~m})$ & $1-7$ & 11 & 15.5 \\
\hline
\end{tabular}


Table 4. Raw data for month of death distributions for sheep/goats from Hârşova tell and Borduşani-Popină. Values (average and standard deviation, $1 \sigma$ ) obtained after 1000 random runs for each of the hemimandibles ( $N=60$ and $N=50)$, for each hypothesis. See the text (4.1.) for explanation of the methodology. A: hypothesis A (birth period: February-March-April); B: hypothesis B (birth period: March-April-May).

Site N Hyp. March April May June July August September October November December January February Hârşova $\quad 60 \quad$ A $4.16( \pm 1.89) 2.84( \pm 1.45) 1.51( \pm 1.11) 1.11( \pm 0.98) 1.67( \pm 1.13) 2.04( \pm 1.22) 1.95( \pm 1.22) \quad 5.47( \pm 2.22) \quad 8.83( \pm 2.66) 12.82( \pm 3.07) 9.92( \pm 2.85) 7.67( \pm 2.54)$ Borduşani $50 \quad$ A $3.85( \pm 1.71) 2.48( \pm 1.48) 1.38( \pm 1.10) 1.64( \pm 1.10) 1.73( \pm 1.16) 1.82( \pm 1.21) 1.69( \pm 1.20) \quad 4.46( \pm 1.94) 6.79( \pm 2.42) \quad 9.45( \pm 2.69) 7.99( \pm 2.51) 6.74( \pm 2.40)$ Hârşova $\quad 60 \quad$ B $7.80( \pm 2.43) 4.31( \pm 1.86) 2.88( \pm 1.54) 1.46( \pm 1.10) 1.12( \pm 0.94) 1.65( \pm 1.16) 2.05( \pm 1.25) \quad 1.99( \pm 1.27) 5.42( \pm 2.10) \quad 8.75( \pm 2.75) 12.52( \pm 2.95) 10.05( \pm 2.78)$

Borduşani 50 B $6.67( \pm 2.34) 4.03( \pm 1.87) 2.44( \pm 1.48) 1.48( \pm 1.06) 1.61( \pm 1.12) 1.77( \pm 1.18) \quad 1.78( \pm 1.25) \quad 1.69( \pm 1.22) \quad 4.25( \pm 1.92) 6.67( \pm 2.36) \quad 9.61( \pm 2.75) \quad 8.00( \pm 2.53)$ 
Table 5. Regression models and theoretical formulae used for examining the relationship between dP4 crown height and age estimate in sheep/goats. For each model, the values (for parameters, $R^{2}$ and mean absolute error) are the averages $( \pm 1 \sigma)$ after 1000 random runs. aCH: anterior crown height; $\mathrm{pCH}$ : posterior crown height; $\mathrm{CHo}$ : unworn crown height; AGEs: age at which the dP4 is shed; O: Ovis. See the text (4.1.5.) for explanation of the methodology.

Under-/over-

\begin{tabular}{|c|c|c|c|c|c|c|c|c|c|c|c|}
\hline Nonlinear regressions & $\begin{array}{l}\text { Crown } \\
\text { height }\end{array}$ & $\mathrm{N}$ & Solver constraints & $\mathrm{p}$ & Intercept & $\mathrm{CHo}$ & $\mathrm{CHmin}$ & $\mathrm{R}^{2}$ & $\begin{array}{l}\text { Mean absolute } \\
\text { error (mths) }\end{array}$ & $\begin{array}{l}95 \% \text { interval } \\
\text { (mths) }\end{array}$ & $\begin{array}{l}\text { estimation of } \\
\text { age }\end{array}$ \\
\hline Natural logarithm function & $\mathrm{aCH}$ & 110 & $13.5 \leq \mathrm{CH} 0 \leq 15 ; \mathrm{CH} \min \geq 0$ & $10.436( \pm 0.128)$ & I & $15(-0)$ & $0(+0)$ & $0.412( \pm 0.063)$ & $1.656( \pm 1.279)$ & $-3.984-4.355$ & $53 \% / 47 \%$ \\
\hline $\mathrm{Age}=-\mathrm{pLn}((\mathrm{CH}-\mathrm{CH} \min ) /(\mathrm{CHo}-$ & $\mathrm{aCH}$ & 110 & $\mathrm{CH}=0 \Rightarrow \mathrm{Age}=33 ; \mathrm{CHo} \leq 15$ & $11.614( \pm 0.200)$ & l & $15(-0)$ & $-0.930( \pm 0.048)$ & $0.442( \pm 0.058)$ & $1.614( \pm 1.247)$ & $-3.968-4.181$ & $51 \% / 49 \%$ \\
\hline \multirow[t]{5}{*}{ CHmin)) } & $\mathrm{aCH}$ & 110 & $\begin{array}{l}\mathrm{CH}=0 \Rightarrow \mathrm{Age}=25.5 \\
\mathrm{CHo} \leq 15\end{array}$ & $13.920( \pm 0.352)$ & I & $15(-0)$ & $-2.860( \pm 0.158)$ & $0.473( \pm 0.051)$ & $1.565( \pm 1.220)$ & $-3.925-4.008$ & $50 \% / 50 \%$ \\
\hline & $\mathrm{aCH}$ & 110 & $\begin{array}{l}\mathrm{CH}=0 \Rightarrow 22 \leq \mathrm{Age} \leq 33 ; \\
\mathrm{CHo} \leq 15\end{array}$ & $17.536( \pm 0.746)$ & $22(+0)$ & $14.980( \pm 0.089)$ & $-5.978( \pm 0.429)$ & $0.492( \pm 0.046)$ & $1.530( \pm 1.205)$ & $-3.889-3.900$ & $49 \% / 51 \%$ \\
\hline & $\mathrm{aCH}$ & $99(\mathrm{O})$ & $\begin{array}{l}\mathrm{CH}=0 \Rightarrow \mathrm{Age}=25.5 \\
\mathrm{CHo} \leq 15\end{array}$ & $14.048( \pm 0.366)$ & / & $15(-0)$ & $-2.918( \pm 0.165)$ & $0.457( \pm 0.067)$ & $1.432( \pm 1.058)$ & $-3.499-3.620$ & $50 \% / 50 \%$ \\
\hline & $\mathrm{pCH}$ & 108 & $16.7 \leq \mathrm{CHo} \leq 18 ; \mathrm{CH} \min \geq 0$ & $13.426( \pm 0.172)$ & I & $18(-0)$ & $0(+0)$ & $0.119( \pm 0.110)$ & $1.994( \pm 1.456)$ & $-4.357-5.328$ & $61 \% / 39 \%$ \\
\hline & $\mathrm{pCH}$ & 108 & $\mathrm{CH}=16.7 \Rightarrow 2 \leq \mathrm{Age} \leq 4$ & $9.403( \pm 1.131)$ & I & $29.314( \pm 3.065)$ & $-2.062( \pm 0.521)$ & $0.437( \pm 0.047)$ & $1.566( \pm 1.210)$ & $-3.960-3.956$ & $51 \% / 49 \%$ \\
\hline
\end{tabular}

Theoretical formulae

$\mathrm{CH}=16.7 \Rightarrow 2 \leq \mathrm{Age} \leq 4$ $29.314( \pm 3.065)-2.062( \pm 0.521) \quad 0.437( \pm 0.047) \quad 1.566( \pm 1.210)-3.960-3.956 \quad 51 \% / 49 \%$

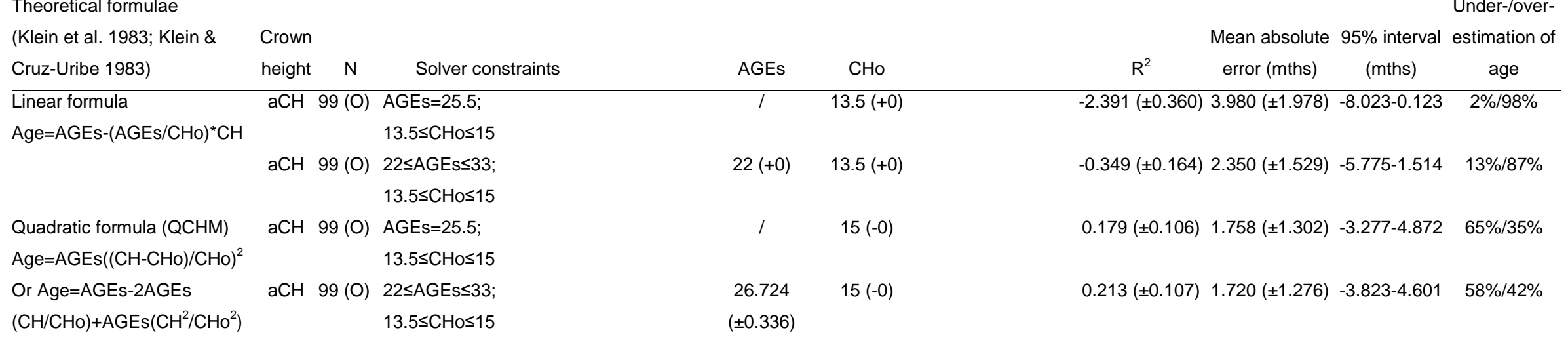


Table 6. Spawning periods of the fish species identified at Hârşova tell and Borduşani-Popină. NISP: number of identified specimens. The last column indicates the requisite temperature for spawning. ${ }^{*}$ identifies Cyprinids.

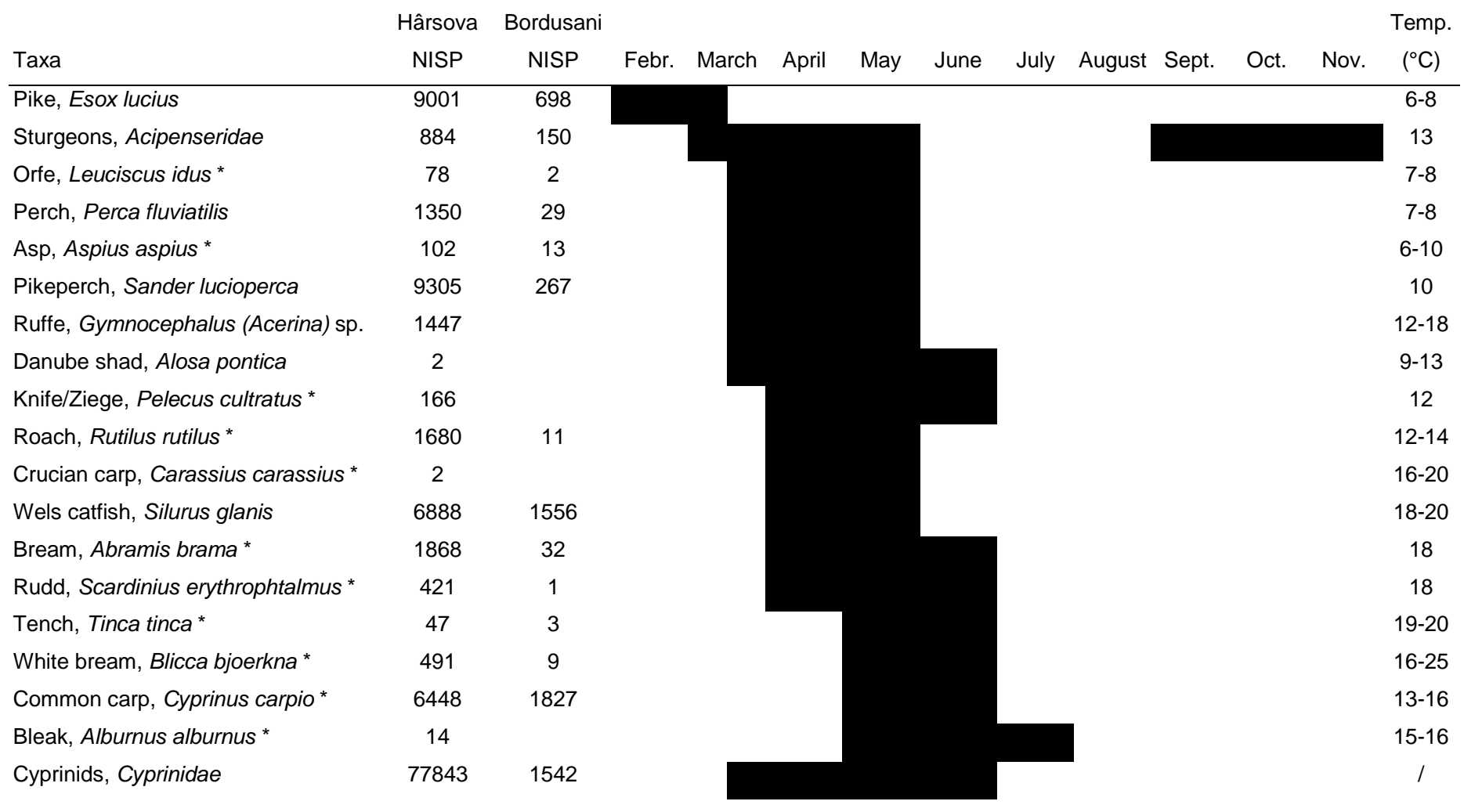


Table 7. Raw data for size distributions for the common carp (Cyprinus carpio) and pikeperch (Sander lucioperca) from Hârşova tell and Borduşani-Popină. TL: total length. See the text (4.2.) for explanation of the methodology.

Pikeperch

$\mathrm{TL}(\mathrm{mm})$

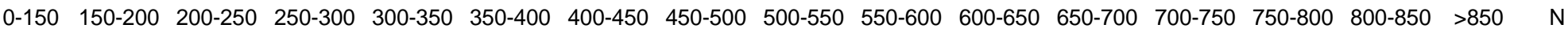

\begin{tabular}{|c|c|c|c|c|c|c|c|c|c|c|c|c|c|c|c|c|c|}
\hline Hârşova tell & 0 & 2 & 16 & 28 & 37 & 26 & 32 & 41 & 37 & 39 & 31 & 18 & 10 & 6 & 2 & 4 & 329 \\
\hline Borduşani-P. & 0 & 0 & 0 & 0 & 0 & 1 & 2 & 3 & 6 & 3 & 2 & 0 & 1 & 1 & 2 & 1 & 22 \\
\hline $\begin{array}{l}\text { Common carp } \\
\text { TL (mm) }\end{array}$ & $0-100$ & $100-200$ & $200-300$ & $300-400$ & $400-500$ & $500-600$ & $600-700$ & $700-800$ & $800-900$ & $\begin{array}{l}900- \\
1000\end{array}$ & $\begin{array}{l}1000- \\
1100\end{array}$ & $\begin{array}{l}1100- \\
1200\end{array}$ & $\begin{array}{l}1200- \\
1300\end{array}$ & & & & $\mathrm{~N}$ \\
\hline Hârşova tell & 4 & 26 & 11 & 32 & 61 & 90 & 87 & 40 & 33 & 22 & 7 & 8 & 1 & & & & 422 \\
\hline Borduşani-P. & 9 & 30 & 50 & 15 & 3 & 7 & 10 & 4 & 8 & 3 & 5 & 0 & 0 & & & & 144 \\
\hline
\end{tabular}


Supplementary Material 1. Pairwise comparisons between estimated means obtained for month of death distributions for sheep/goats (raw data in Table 4) using paired t-test; p-value adjustment method: Bonferroni. A: hypothesis A; B: hypothesis B. Grey cells indicate no significant difference.

\begin{tabular}{|c|c|c|c|c|c|c|c|c|c|c|c|}
\hline Hârsova-A & March & April & May & June & July & August & Sept. & Oct. & Nov. & Dec. & Jan. \\
\hline April & $5.81 \mathrm{E}-50$ & & & & & & & & & & \\
\hline May & $1.33 \mathrm{E}-180$ & $2.04 \mathrm{E}-85$ & & & & & & & & & \\
\hline June & 3.75E-244 & $2.22 \mathrm{E}-141$ & $1.05 \mathrm{E}-12$ & & & & & & & & \\
\hline July & $4.58 \mathrm{E}-179$ & $1.18 \mathrm{E}-73$ & 0.089 & $1.25 \mathrm{E}-24$ & & & & & & & \\
\hline August & $1.46 \mathrm{E}-136$ & 8.83E-36 & 8.96E-21 & $2.50 \mathrm{E}-57$ & 3.03E-08 & & & & & & \\
\hline September & 5.67E-148 & $5.12 \mathrm{E}-44$ & $7.45 \mathrm{E}-15$ & 3.04E-49 & 0.000111 & 1 & & & & & \\
\hline October & 3.92E-38 & $1.15 \mathrm{E}-143$ & 1.13E-269 & $1.78 \mathrm{E}-304$ & 7.14E-252 & $5.04 \mathrm{E}-214$ & 2.38E-212 & & & & \\
\hline November & $6.74 \mathrm{E}-237$ & 0 & 0 & 0 & 0 & 0 & 0 & $3.48 \mathrm{E}-126$ & & & \\
\hline December & 0 & 0 & 0 & 0 & 0 & 0 & 0 & $2.15 \mathrm{E}-316$ & $2.16 \mathrm{E}-121$ & & \\
\hline January & 2.96E-273 & 0 & 0 & 0 & 0 & 0 & 0 & $1.20 \mathrm{E}-184$ & $6.89 \mathrm{E}-13$ & $2.14 \mathrm{E}-68$ & \\
\hline February & $1.72 \mathrm{E}-154$ & 5.09E-268 & 0 & 0 & 0 & 0 & 0 & $1.89 \mathrm{E}-74$ & $7.29 \mathrm{E}-18$ & 4.77E-181 & 3.86E-56 \\
\hline
\end{tabular}

\begin{tabular}{|c|c|c|c|c|c|c|c|c|c|c|c|}
\hline Bordusani-A & March & April & May & June & July & August & Sept. & Oct. & Nov. & Dec. & Jan. \\
\hline April & 6.39E-61 & & & & & & & & & & \\
\hline May & $2.02 \mathrm{E}-193$ & $1.50 \mathrm{E}-61$ & & & & & & & & & \\
\hline June & $5.66 \mathrm{E}-166$ & $1.40 \mathrm{E}-38$ & $6.46 \mathrm{E}-05$ & & & & & & & & \\
\hline July & $4.50 \mathrm{E}-153$ & $1.86 \mathrm{E}-30$ & $9.32 \mathrm{E}-09$ & 1 & & & & & & & \\
\hline August & 3.77E-147 & $1.04 \mathrm{E}-22$ & $2.88 \mathrm{E}-14$ & 0.1271 & 1 & & & & & & \\
\hline September & 2.13E-159 & $9.50 \mathrm{E}-34$ & 4.91E-07 & 1 & 1 & 1 & & & & & \\
\hline October & $6.44 \mathrm{E}-11$ & 7.52E-109 & $2.48 \mathrm{E}-236$ & 1.14E-207 & $7.51 \mathrm{E}-189$ & $2.98 \mathrm{E}-170$ & $1.18 \mathrm{E}-186$ & & & & \\
\hline November & $1.07 \mathrm{E}-139$ & 3.43E-250 & 0 & 0 & 0 & $1.94 \mathrm{e}-313$ & $3.18 \mathrm{e}-315$ & $2.08 \mathrm{E}-85$ & & & \\
\hline December & 2.09E-295 & 0 & 0 & 0 & 0 & 0 & 0 & $1.79 \mathrm{E}-240$ & 1.36E-75 & & \\
\hline January & 3.95E-211 & 7.97E-318 & 0 & 0 & 0 & 0 & 0 & $7.55 \mathrm{E}-158$ & 1.96E-20 & $5.60 \mathrm{E}-25$ & \\
\hline February & $2.93 \mathrm{E}-126$ & 1.99E-248 & 0 & 0 & 0 & $1.68 e-316$ & 0 & 1.11E-86 & 1 & 1.34E-81 & 7.12E-22 \\
\hline
\end{tabular}




\section{Supplementary Material 1. Continued}

\begin{tabular}{|c|c|c|c|c|c|c|c|c|c|c|c|}
\hline Hârsova-B & April & May & June & July & August & Sept. & Oct. & Nov. & Dec. & Jan. & Feb. \\
\hline May & 2.32E-52 & & & & & & & & & & \\
\hline June & 7.30E-210 & $5.52 \mathrm{E}-87$ & & & & & & & & & \\
\hline July & 4.83E-261 & $3.72 \mathrm{E}-141$ & $4.52 \mathrm{E}-11$ & & & & & & & & \\
\hline August & $3.89 E-196$ & 2.01E-76 & 0.0465 & $2.29 \mathrm{E}-21$ & & & & & & & \\
\hline September & $2.38 \mathrm{E}-155$ & 5.52E-36 & 1.38E-22 & $2.49 E-57$ & 6.59E-09 & & & & & & \\
\hline October & $1.93 \mathrm{E}-150$ & $7.12 \mathrm{E}-40$ & $1.64 \mathrm{E}-19$ & $1.23 E-55$ & 4.92E-07 & 1 & & & & & \\
\hline November & $4.95 \mathrm{E}-30$ & $3.16 \mathrm{E}-141$ & 8.92E-287 & $4.82 \mathrm{e}-319$ & 1.36E-259 & 2.47E-231 & 5.12E-219 & & & & \\
\hline December & $6.49 \mathrm{E}-215$ & 0 & 0 & 0 & 0 & 0 & 0 & $9.07 \mathrm{E}-126$ & & & \\
\hline January & 0 & 0 & 0 & 0 & 0 & 0 & 0 & $9.40 \mathrm{e}-316$ & $8.45 \mathrm{E}-111$ & & \\
\hline February & 1.77E-289 & 0 & 0 & 0 & 0 & 0 & 0 & $2.80 \mathrm{E}-205$ & $2.78 \mathrm{E}-18$ & $1.15 \mathrm{E}-54$ & \\
\hline March & $4.01 \mathrm{E}-167$ & 3.64E-282 & 0 & 0 & 0 & 0 & 0 & $2.28 \mathrm{E}-90$ & $1.42 \mathrm{E}-11$ & $3.41 \mathrm{E}-180$ & $1.36 \mathrm{E}-57$ \\
\hline Bordusani-B & April & May & June & July & August & Sept. & Oct. & Nov. & Dec. & Jan. & Feb. \\
\hline May & 3.60E-72 & & & & & & & & & & \\
\hline June & $4.28 \mathrm{E}-179$ & 2.04E-52 & & & & & & & & & \\
\hline July & $6.45 \mathrm{E}-177$ & $2.62 E-37$ & 0.8000 & & & & & & & & \\
\hline August & 5.07E-157 & 8.36E-25 & 6.67E-06 & 0.3652 & & & & & & & \\
\hline September & $5.15 \mathrm{E}-150$ & $1.24 \mathrm{E}-23$ & $1.32 \mathrm{E}-06$ & 0.2597 & 1 & & & & & & \\
\hline October & $6.76 \mathrm{E}-160$ & 7.45E-33 & 0.0042 & 1 & 1 & 1 & & & & & \\
\hline November & 0.6573 & 1.06E-94 & $3.20 \mathrm{E}-210$ & $1.02 \mathrm{E}-186$ & $4.00 \mathrm{E}-170$ & $4.48 \mathrm{E}-160$ & 7.67E-166 & & & & \\
\hline December & $1.53 \mathrm{E}-115$ & $7.25 \mathrm{E}-254$ & 0 & 0 & 0 & $5.03 e-312$ & $3.91 \mathrm{e}-321$ & 1.64E-96 & & & \\
\hline January & 3.07E-271 & 0 & 0 & 0 & 0 & 0 & 0 & $1.74 \mathrm{E}-253$ & 4.34E-91 & & \\
\hline February & $3.24 \mathrm{E}-188$ & $3.28 \mathrm{e}-317$ & 0 & 0 & 0 & 0 & 0 & $5.31 \mathrm{E}-172$ & $1.70 \mathrm{E}-25$ & 5.24E-29 & \\
\hline March & $8.74 \mathrm{E}-112$ & $3.94 \mathrm{E}-245$ & 0 & 0 & 0 & $7.17 \mathrm{e}-320$ & 0 & 7.85E-98 & 1 & 4.43E-92 & 4.87E-26 \\
\hline
\end{tabular}




\section{Figure captions}

Figure 1. Location of the two Eneolithic sites included in the study.

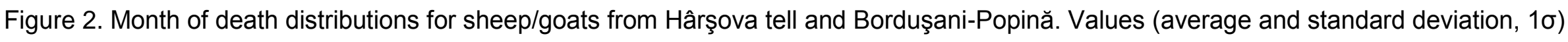
obtained after 1000 random runs for each of the hemimandibles $(\mathrm{N}=60$ and $\mathrm{N}=50)$, for each hypothesis. $A$ : hypothesis $A$ (birth period: FebruaryMarch-April); B: hypothesis B (birth period: March-April-May). Grey areas indicate summer and winter. Months overlapping the two groups identified (see the text) are underlined. See the text (4.1.) for explanation of the methodology and Table 4 for raw data.

Figure 3. Month of death distributions for three archaeological structures/unit from Hârşova tell. Percentages are calculated from values obtained after 1000 random runs for each of the eleven hemimandibles, hypothesis B (birth period: March-April-May). The curve shows the percentages for the whole site. See the text (4.1.) for explanation of the methodology.

Figure 4. Month of death distributions for goats from Hârşova tell and Borduşani-Popină. Percentages are calculated from values obtained after 1000 random runs for each of the six hemimandibles, hypothesis B (birth period: March-April-May). Hva: Hârşova tell; Bord: Borduşani-Popină. The curves show the percentages for the whole assemblages. See the text (4.1.) for explanation of the methodology. 
Figure 5. Sheep/goat dP4 crown heights $(\mathrm{aCH})$ plotted against age estimates (data from Hârşova tell and Borduşani-Popină). Sheep: 99 hemimandibles (in black); goats: 11 hemimandibles (in grey). Fifteen supplementary hemimandibles of sheep are plotted (dotted lines) but they are not included in the calculations. B: same plot with fitting curves 1 and 3 (natural logarithm function; Table 5). See the text (4.1.5.) for explanation of the methodology and Table 3 for raw data.

Figure 6. Same plot than in Figure 5A, with age estimates based on the theoretical formulae from Klein et al. (1983). Linear and quadratic formulae are calculated for sheep (Table 5). The fitting curve (natural logarithm function) is calculated from sheep remains only (Table 5). All intercepts are at 25.5 months. See the text (4.1.5.) for explanation of the methodology.

Figure 7. Size distributions for the common carp (Cyprinus carpio) and pikeperch (Sander lucioperca) from Hârşova tell and Borduşani-Popină. TL: total length. Arrows indicate averages. Grey areas indicate the limits for sexually mature fish (see the text). See the text (4.2.) for explanation of the methodology. 


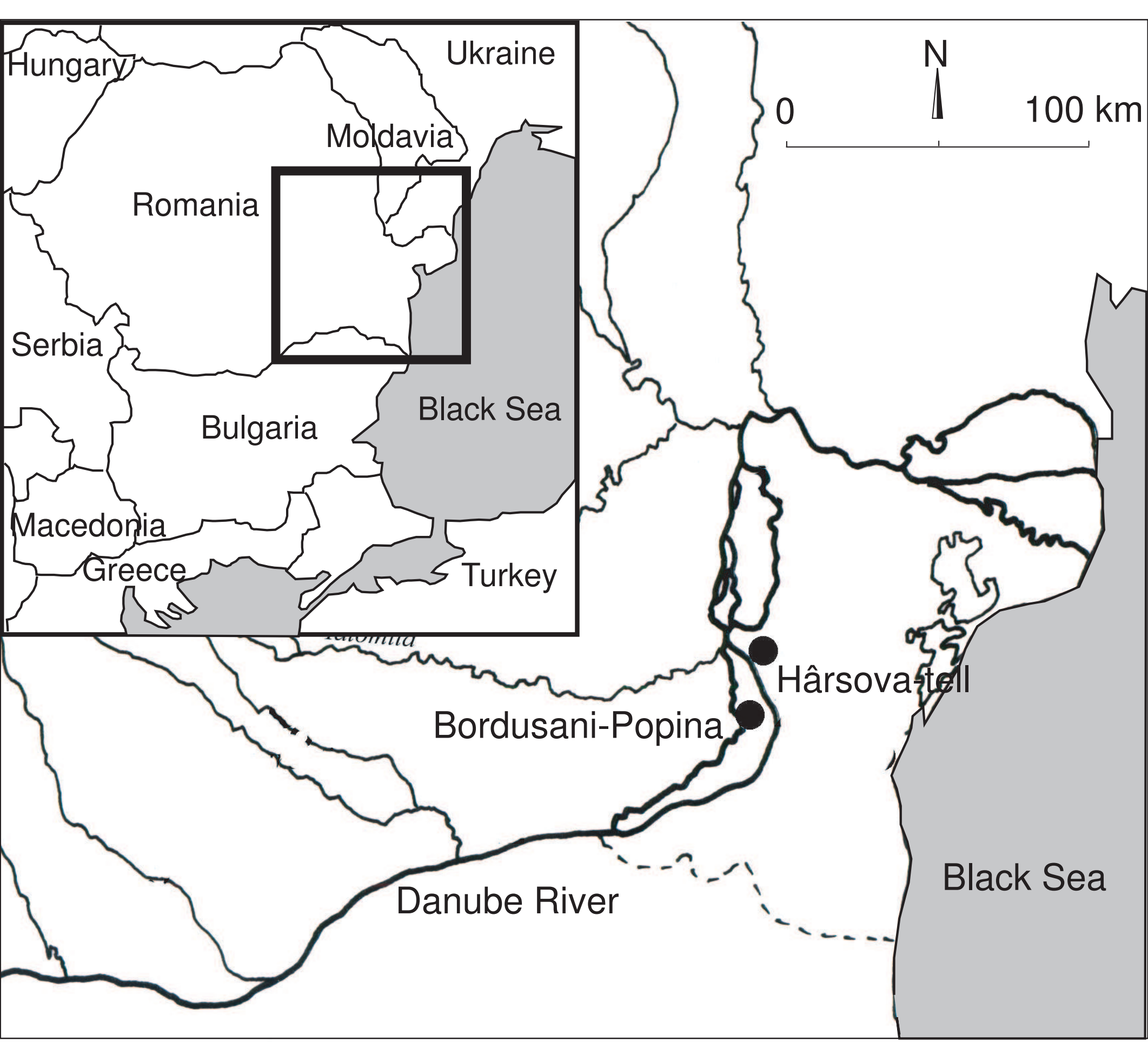


Hyp. A
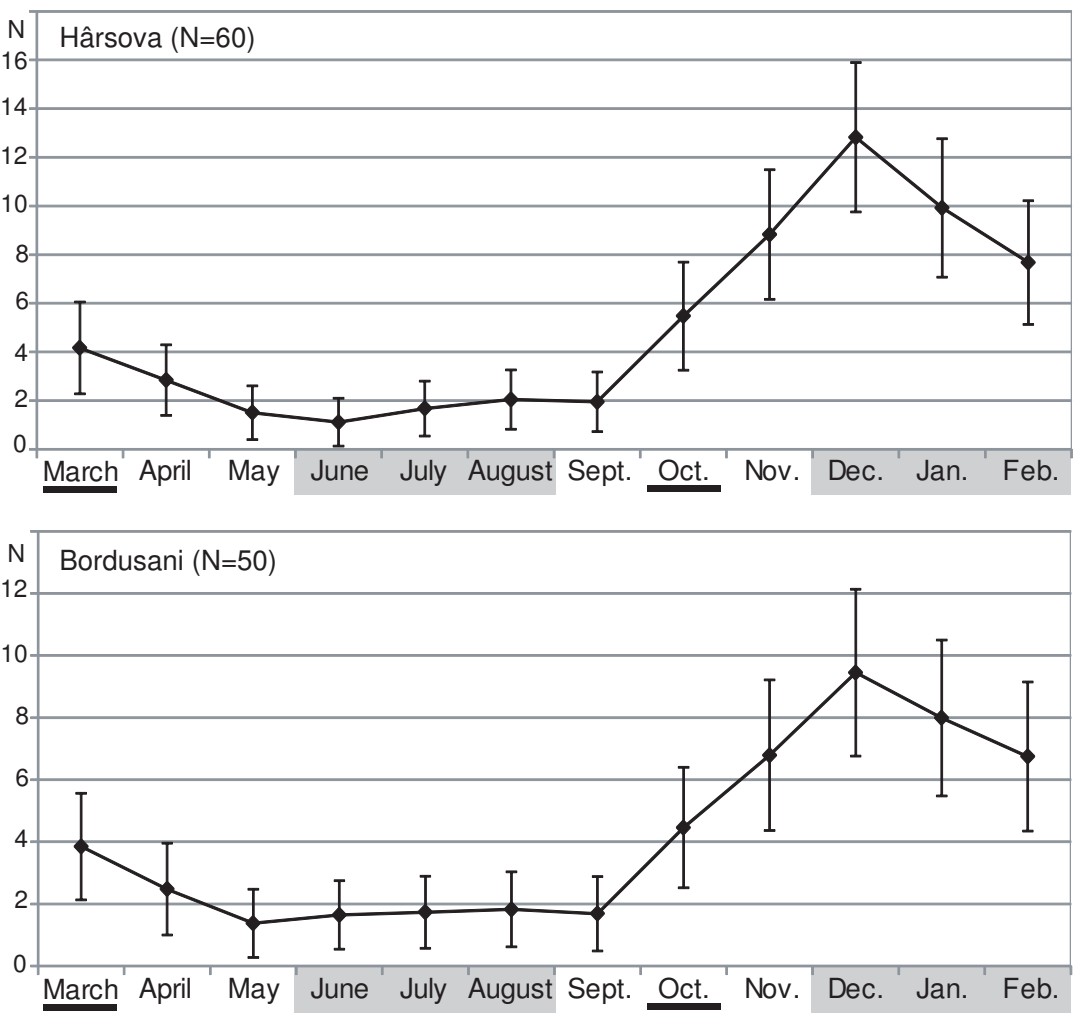

Hyp. B
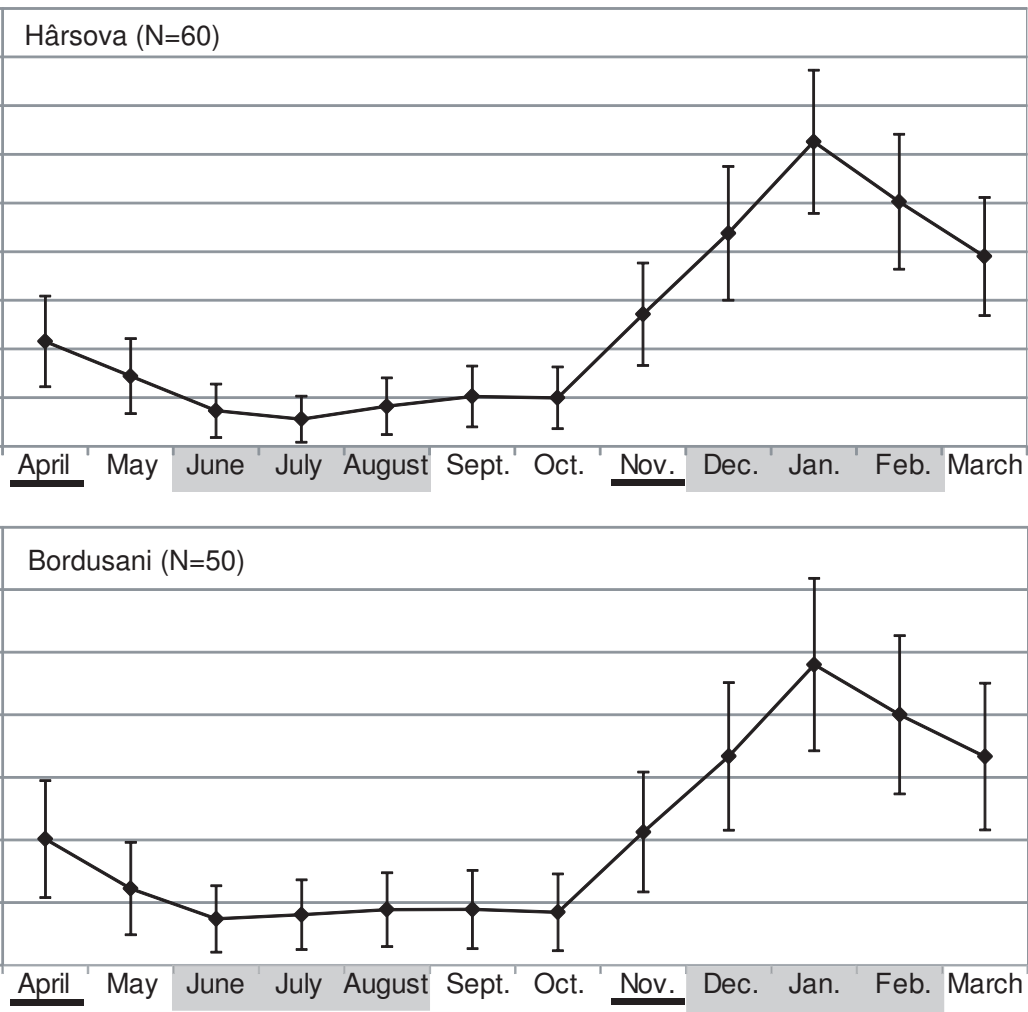


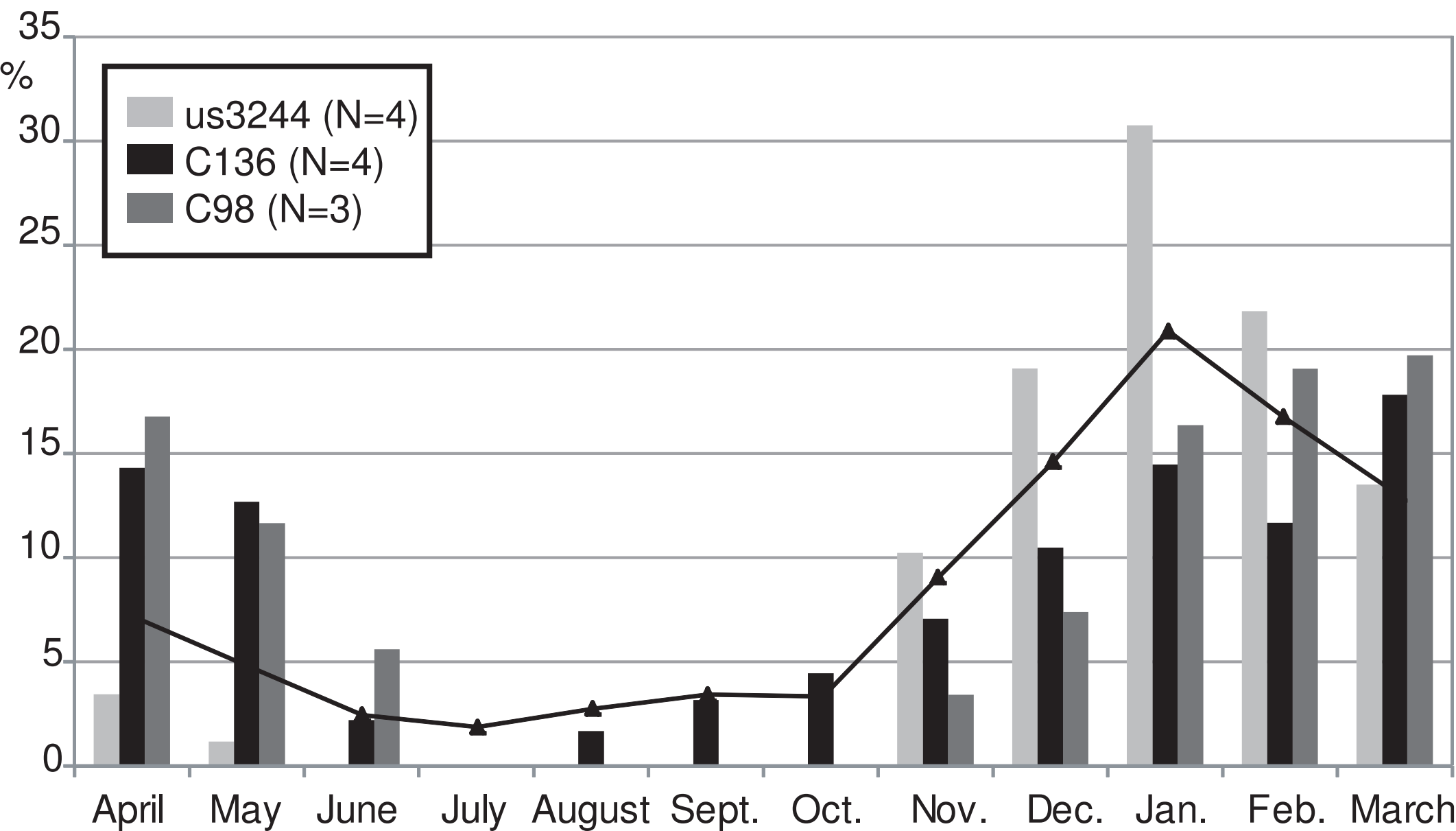

April May June July August Sept. Oct. Nov. Dec. Jan. Feb. March 


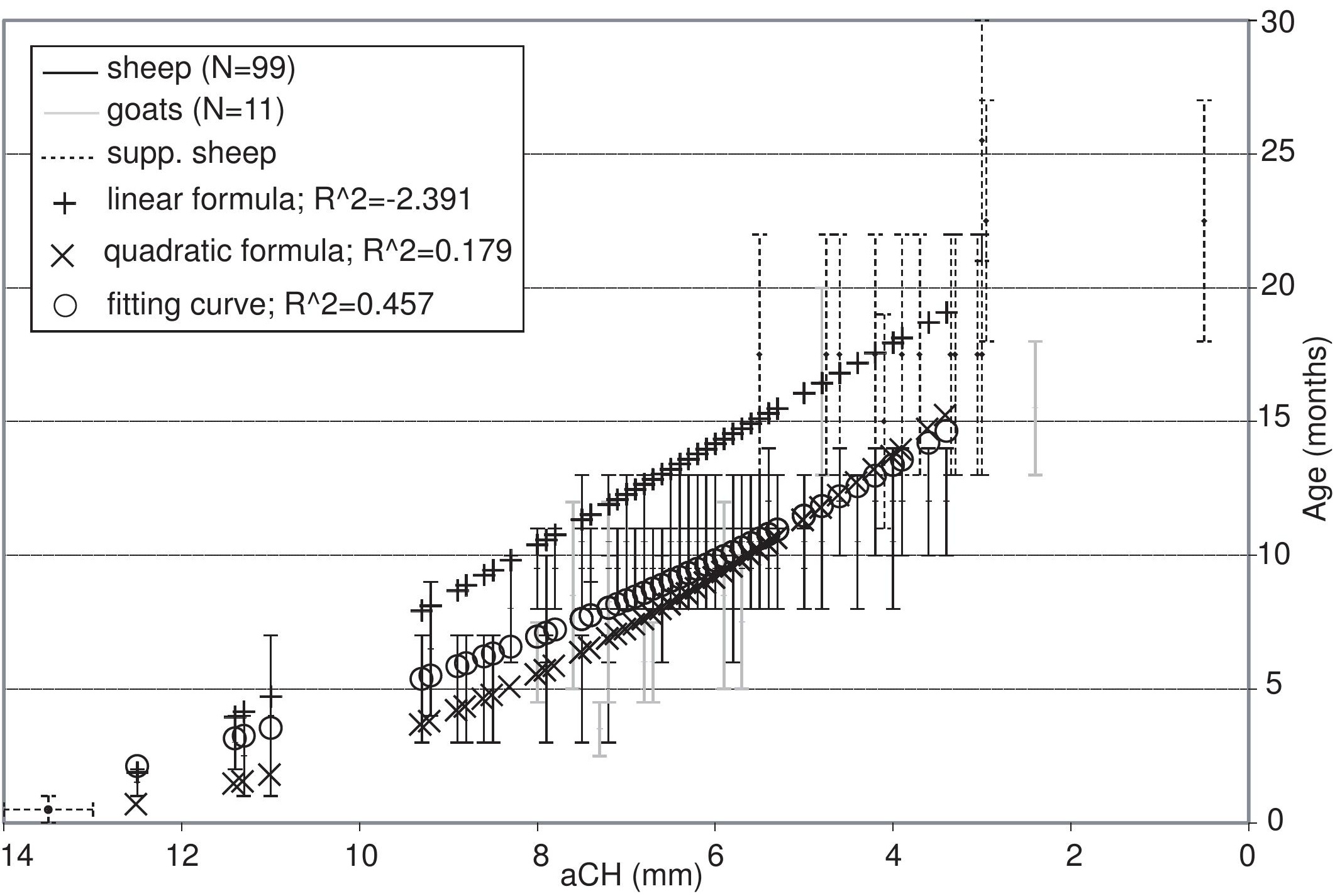




\section{BIOGRAPHICAL NOTES}

Stéphanie Bréhard (PhD 2007) is a postdoctoral researcher in zooarchaeology at the Muséum national d'Histoire naturelle, Paris. Her research interests are herding practices, settlement function, and land use. She works on western and south-eastern European societies and her research focuses on Neolithic and Eneolithic periods.

Address: CNRS - Muséum national d'Histoire naturelle, UMR 7209, CP 56, 55 rue Buffon, F75005 Paris, France. [email: brehard@mnhn.fr]

Valentin Radu is a zooarchaeologist at the National Museum of Romanian History, Bucharest. He specialized in ichthyology and malacology. His research interests are food strategies of the prehistoric communities based on aquatic resources, palaeoenvironmental and palaeoclimatic reconstructions, and palaeoecological and biogeographic studies. $\mathrm{He}$ works on different chronological periods in Romania, France, Iran, Russia and Armenia.

Address: National History Museum of Romania, CNCP, Calea Victoriei nr. 12, 030026, sector 3, Bucharest, Romania. [email: raduvalentin@hotmail.com]

Alexis Martin is an engineer at the Muséum national d'Histoire naturelle, Paris. He works on automation of data analysis processes, creation of computer based simulations and development of scientific databases.

Address: Muséum national d'Histoire naturelle, UMR 7208, 43 rue Cuvier, F-75005 Paris, France. [email: alexis.martin@mnhn.fr]

Pauline Hanot is graduated from the Muséum national d'Histoire naturelle (Paris) with a master's degree. She studies fauna from rescue archaeology operations, conducted on 
French historic sites (Centre de Recherche Archéologique de la Vallée de l'Oise, Compiègne). She has a specific research interest in equids morphology.

Address: Muséum national d'Histoire naturelle, UMR 7209, CP 56, 55 rue Buffon, F-75005 Paris, France. [email: pauline_hanot@hotmail.fr]

Dragomir Nicolae Popovici is an archaeologist at the National History Museum of Romania, Bucharest. The Chalcolithic is his main area of interest, and he has directed several excavations from this period.

Address: National History Museum of Romania, CNCP, Calea Victoriei nr. 12, 030026, sector 3, Bucharest, Romania. [email: dnp@mnir.ro]

Adrian Bălăşescu is a zooarchaeologist at the National Museum of Romanian History, Bucharest. He participated in various research teams at numerous archaeological excavations (in Romania, France and Armenia) being responsible mainly for the zooarchaeological investigation. His background is in Balkan prehistory and he also has research interests in Armenia Neolithic and Chalcolithic zooarchaeology.

Address: National History Museum of Romania, CNCP, Calea Victoriei nr. 12, 030026, sector 3, Bucharest, Romania. [email: abalasescu2005@yahoo.fr] 